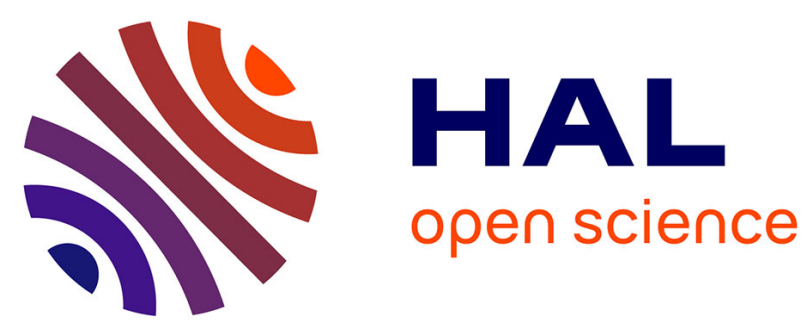

\title{
A New Phosphonium Calix[4]arene for Selective Anion Recognition: Synthesis and Studies in Solution and in Ion Selective Electrodes
}

Radoslaw Pomeæko, Zouhair Asfari, Veronique Hubscher, Maria Krystyna Bocheńska, Françoise Arnaud-Neu

\section{To cite this version:}

Radoslaw Pomeæko, Zouhair Asfari, Veronique Hubscher, Maria Krystyna Bocheńska, Françoise Arnaud-Neu. A New Phosphonium Calix[4]arene for Selective Anion Recognition: Synthesis and Studies in Solution and in Ion Selective Electrodes. Supramolecular Chemistry, 2007, 19 (07), pp.459466. 10.1080/10610270601123995 . hal-00513501

\section{HAL Id: hal-00513501 https://hal.science/hal-00513501}

Submitted on 1 Sep 2010

HAL is a multi-disciplinary open access archive for the deposit and dissemination of scientific research documents, whether they are published or not. The documents may come from teaching and research institutions in France or abroad, or from public or private research centers.
L'archive ouverte pluridisciplinaire HAL, est destinée au dépôt et à la diffusion de documents scientifiques de niveau recherche, publiés ou non, émanant des établissements d'enseignement et de recherche français ou étrangers, des laboratoires publics ou privés. 


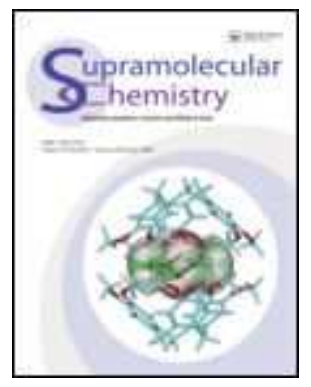

\section{A New Phosphonium Calix[4]arene for Selective Anion Recognition: Synthesis and Studies in Solution and in Ion Selective Electrodes}

\begin{tabular}{|r|l|}
\hline Journal: & Supramolecular Chemistry \\
\hline Manuscript ID: & GSCH-2006-0044.R1 \\
\hline Manuscript Type: & Full Paper \\
\hline Author: & 09-Nov-2006 \\
\hline Complete List of Authors: & $\begin{array}{l}\text { Pomeæko, Radosław; Gdañsk University of Technology } \\
\text { Asfari, Zouhair; Universite' Louis PasteursEcole Europeenne Chimie } \\
\text { Polymeres Materiaux } \\
\text { Hubscher, Veronique; Universite' Louis PasteursEcole Europeenne } \\
\text { Chimie Polymeres Materiaux } \\
\text { Bocheńska, Maria; Gdañsk University of Technology, of Chemical } \\
\text { Technology } \\
\text { Arnaud-Neu, Françoise; Universite' Louis PasteursEcole } \\
\text { Europeenne Chimie Polymeres Materiaux }\end{array}$ \\
\hline Keywords: & $\begin{array}{l}\text { calix[4]arene, perchlorate, phosphonium group, anion } \\
\text { complexation, ISE }\end{array}$ \\
\hline $\begin{array}{l}\text { RP scheme 1.cdx } \\
\text { RP scheme 2.cdx } \\
\text { to PDF. You must view these files (e.g. movies) online. }\end{array}$ \\
\hline \hline
\end{tabular}

\section{今 ScholarONE" \\ Manuscript Central}




\title{
A New Phosphonium Calix[4]arene for Selective Anion
}

\author{
Recognition: Synthesis and Studies in Solution and in Ion \\ Selective Electrodes
}

\author{
Radoslaw Pomecko, ${ }^{a, b}$ Zouhair Asfari, ${ }^{a}$ Véronique Hubscher-Bruder, ${ }^{a}$ \\ Maria Bochenska, ${ }^{b, c}$ and Françoise Arnaud-Neu, ${ }^{a, c}$ \\ ${ }^{\mathrm{a}}$ Department of Analytical Sciences, IPHC, UMR 7178 (CNRS-ULP), \\ Ecole Européenne de Chimie, Polymères, Matériaux (ECPM), \\ 25 rue Becquerel, 67087 Strasbourg Cedex 2, France \\ ${ }^{\mathrm{b}}$ Department of Chemical Technology, Chemical Faculty, \\ Gdansk University of Technology, ul. Narutowicza 11/12, 80-264 Gdansk, Poland; \\ ${ }^{c}$ Authors to whom correspondence should be addressed \\ (e-mail: farnaud@ chimie.u-strasbg.fr; marboch@altis.chem.pg.gda.pl)
}

\begin{abstract}
The synthesis and characterisation of a new tetra (triphenylphosphonium) p-tertbutylcalix[4]arene $\mathbf{2}$ is presented. Its interactions with anions were studied by ${ }^{1} \mathrm{H}$ and ${ }^{31} \mathrm{P}$ NMR and UV absorption spectrophotometry, showing the biggest interaction with $\mathrm{ClO}_{4}^{-}, \mathrm{I}^{-}$and $\mathrm{SCN}^{-}$. Anion selectivity in ion-selective PVC-membrane electrodes (ISEs) plasticized with o-NPOE containing ionophore $\mathbf{2}$ was also
\end{abstract}


investigated. Compound 2 shows a potentiometric response for various anions with the following selectivity pattern: $\mathrm{ClO}_{4}^{-}>\mathrm{SCN}^{-}>\mathrm{I}^{-}>\mathrm{Cr}_{2} \mathrm{O}_{7}^{2-}>\mathrm{NO}_{3}^{-}>\mathrm{Br}^{-}>\mathrm{Cl}^{-}$. Key Words: calix[4]arene, perchlorate, phosphonium group, anion complexation, ISE

\section{INTRODUCTION}

Anions play an important role in biological processes, e.g. in enzymatic reactions or in DNA coding. ${ }^{1}$ Perturbation of the anionic equilibria in organisms may be the origin of diseases. The increase of anion concentrations in ecosystems leads to environmental problems such as eutrophication due to an excess of phosphates and nitrates or the presence of long-lived radioelements such as iodine, technetium, and selenium in their anionic forms produced by the nuclear industry. ${ }^{2}$ Anions are relatively large and have also a wide variety of geometries which are important factors to be considered in the design of selective anion receptors. Therefore the recognition of anions is a topical challenge.

Design of sensors for monitoring the activity of chemical and biochemical species is an important issue in supramolecular chemistry. ${ }^{3,4}$ A large number of ionophores for potentiometric sensing of cations have been developed but the number of suitable sensors for anions is still rather limited. ${ }^{5}$ Anion binding can be achieved by neutral receptors (such as urea containing ligands) mainly through hydrogen bonding $^{5,6}$ or by positively charged ligands (for instance guanidinium or polyamine containing macrocycles) through electrostatic interaction. ${ }^{5,7,8}$ Calixarenes were used as molecular scaffold on which to graft such functional groups. ${ }^{9}$ For instance, the synthesis of amide, ${ }^{10-12}$ urea $^{13,14}$ or alkylammonium ${ }^{15}$ and pyridynium ${ }^{16}$ calixarene derivatives selective for anions were reported. ${ }^{17-19}$ The majority of the anion- 


\section{EXPERIMENTAL}

\section{Materials and Methods}

${ }^{1} \mathrm{H}$ and ${ }^{31} \mathrm{P}$ NMR spectra were recorded in $\mathrm{CDCl}_{3}$ and $\mathrm{CD}_{3} \mathrm{CN}$ on a Brucker $\mathrm{SY} 300$ $\mathrm{MHz}$ and a SY400 MHz, respectively. FAB mass spectra were obtained on a VG analytical ZAB HF instrument. All reagents and solvents were commercial and used without further purification, except THF which was dried and freshly distilled before used for preparation of ion selective membranes. PVC (high molecular weight poly(vinyl chloride), 2-nitrophenyl octyl ether (NPOE), bis-ethylhexylsebacate (BEHS), (2-morpholino)ethanesulfonic acid monohydrate (MES), were from Fluka selectophore. The $\mathrm{LiClO}_{4}, \mathrm{CsClO}_{4}$ and sodium salts: $\mathrm{Cl}^{-}, \mathrm{Br}^{-}, \mathrm{I}^{-}, \mathrm{ClO}_{4}^{-}, \mathrm{SCN}^{-}, \mathrm{NO}_{3}^{-}$, $\mathrm{SO}_{4}{ }^{2-}, \mathrm{CO}_{3}{ }^{2-}, \mathrm{HPO}_{4}{ }^{2-}, \mathrm{PO}_{4}{ }^{3-}, \mathrm{Cr}_{2} \mathrm{O}_{7}{ }^{2-}$, citrate, acetate, benzoate, and oxalate were of 
p.a. grade. All aqueous salt solutions were prepared with demineralised water (conductivity $<1.0 \mu \mathrm{S} / \mathrm{cm}$ ).

\section{Synthesis}

Scheme 1

Tetrakis-(4-triphenylphosphonium-butoxy)-tetrakis-p-tert-butylcalix[4]arene tetrabromide 2.

Tetrakis-(4-bromobutoxy)-tetrakis-p-tert-butylcalix[4]arene 1 (1.184 g, $1.00 \mathrm{mmol})$ was dissolved in chloroform $(30 \mathrm{ml})$. After a few minutes of stirring triphenylphosphine $(5.248 \mathrm{~g}, 20.00 \mathrm{mmol})$ and chloroform $(20 \mathrm{ml})$ were added. After 6 days of refluxing the mixture was cooled and solvent was evaporated. The residue was dissolved in dichloromethane. The excess of triphenylphosphine was precipitated from methanol and filtered. The organic layer was evaporated and the crude product was dissolved in dichloromethane. Chromatography on a silica column with 90:10 dichloromethane: methanol mixture as eluent gave tetrakis-(4triphenylphosphonium-butoxy)-tetrakis-p-tert-butylcalix[4] arene tetrabromide (0.67 g, 30\%). $\mathrm{C}_{132} \mathrm{H}_{144} \mathrm{O}_{4} \mathrm{P}_{4} \mathrm{Br}_{4} \quad \mathrm{M}=2238.10 \mathrm{~g} / \mathrm{mole} \delta_{\mathrm{H}}\left(300 \mathrm{MHz} ; \mathrm{CDCl}_{3} ; \mathrm{Me}_{4} \mathrm{Si}\right.$ ) 7.88$7.76(24 \mathrm{H}, \mathrm{m}, \mathrm{P}-\mathrm{Ar}-H), 7.71-7.59(36 \mathrm{H}, \mathrm{m}, \mathrm{P}-\mathrm{Ar}-H), 6.63(8 \mathrm{H}, \mathrm{s}, \mathrm{Ar}-H), 4.23(4 \mathrm{H}$, d, $\left.J=13.0 \mathrm{~Hz}, \mathrm{Ar}-\mathrm{CH}_{2}-\mathrm{Ar}\right), 4.01-3.78\left(16 \mathrm{H}, \mathrm{m},-\mathrm{CH}_{2}-\mathrm{P}\right.$ and $\left.\mathrm{Ar}-\mathrm{O}-\mathrm{CH}_{2}\right), 2.91(4 \mathrm{H}$, $\left.\mathrm{d}, J=13.0 \mathrm{~Hz}, \mathrm{Ar}-\mathrm{CH}_{2}-\mathrm{Ar}\right), 2.41-2.24\left(8 \mathrm{H}, \mathrm{m},-\mathrm{CH}_{2^{-}}\right), 1.72-1.56\left(8 \mathrm{H}, \mathrm{m},-\mathrm{CH}_{2^{-}}\right)$, $1.02\left(36 \mathrm{H}, \mathrm{s},-\mathrm{C}\left(\mathrm{CH}_{3}\right)_{3}\right) . \mathrm{m} / \mathrm{z}(\mathrm{FAB}(+)) 479.5\left(\mathrm{M}^{4+}, 100 \%\right)$. 
Tetrakis-(4-bromobutoxy)-tetrakis-p-tert-butylcalix[4]arene 1. The suspension of ptert-butylcalix[4]arene $(1.947 \mathrm{~g}, 3.00 \mathrm{mmol})$ and $\mathrm{NaH}$ in oil washed three times with hexane $(0.700 \mathrm{~g}, 29.17 \mathrm{mmol})$ were stirred at room temperature in DMF (50 ml) for 1h. Then 1,4-dibromobutane $(12.947 \mathrm{~g}, 59.06 \mathrm{mmol})$ was added and the mixture was heated to $80{ }^{\circ} \mathrm{C}$. After 4 days of heating, the mixture was cooled and $\mathrm{MeOH}(20 \mathrm{ml})$ was added. After removing of the solvent, the residue was dissolved in dichloromethane and water and acidified with $1 \mathrm{M} \mathrm{HCl}$. The organic layer was dried over $\mathrm{Na}_{2} \mathrm{SO}_{4}$, filtered and evaporated. After precipitation from methanol pure tetra(4-bromobutoxy)-tetrakis-p-tert-butylcalix[4]arene $(1.52 \mathrm{~g}, 43 \%)$ was obtained. $\mathrm{C}_{60} \mathrm{H}_{84} \mathrm{O}_{4} \mathrm{Br}_{4} \quad \mathrm{M}=1188.94 \mathrm{~g} / \mathrm{mole} \delta_{\mathrm{H}}\left(300 \mathrm{MHz}, \mathrm{CDCl}_{3}\right) 6.79(8 \mathrm{H}, \mathrm{s}, \mathrm{Ar}-H), 4.36$ $\left(4 \mathrm{H}, \mathrm{d}, J=13.0 \mathrm{~Hz}, \mathrm{Ar}-\mathrm{CH}_{2}-\mathrm{Ar}\right), 3.91\left(8 \mathrm{H}, \mathrm{t}, J=6.9 \mathrm{~Hz},-\mathrm{CH}_{2}-\mathrm{O}-\right), 3.53(8 \mathrm{H}, \mathrm{t}, J=$ $\left.6.9 \mathrm{~Hz},-\mathrm{CH}_{2}-\mathrm{Br}\right), 3.15\left(4 \mathrm{H}, \mathrm{d}, J=13.0 \mathrm{~Hz}, \mathrm{Ar}-\mathrm{CH}_{2}-\mathrm{Ar}\right), 2.23-2.16\left(8 \mathrm{H}, \mathrm{m},-\mathrm{CH}_{2}-\right)$, 2.09-1.98 (8H, m, - $\left.\mathrm{CH}_{2^{-}}\right), 1.09\left(36 \mathrm{H}, \mathrm{s},-\mathrm{C}\left(\mathrm{CH}_{3}\right)_{3}\right)$.

Scheme 2

4-Bromobutoxy-p-tert-butyl-phenol $\mathbf{3}$ and triphenylphosphonium-butoxy-p-tert-butylphenol bromide 4.

Compounds $\mathbf{3}$ and $\mathbf{4}$ were synthesised according to the procedures which were used for the preparation of 1 and 2. Compound 3: $(60 \%) . \mathrm{C}_{14} \mathrm{H}_{21} \mathrm{OBr} \quad \mathrm{M}=285.22 \mathrm{~g} / \mathrm{mole} \delta_{\mathrm{H}}(300$ $\left.\mathrm{MHz}_{\mathrm{CDCl}}\right) 7.32(2 \mathrm{H}, \mathrm{d}, J=9.0 \mathrm{~Hz}, \mathrm{Ar}-H), 6.86(2 \mathrm{H}, \mathrm{d}, J=9.0 \mathrm{~Hz}, \operatorname{Ar}-H), 3.99(2 \mathrm{H}$, $\left.\mathrm{t}, J=5.8, \mathrm{Ar}-\mathrm{O}-\mathrm{CH}_{2}\right), 3.51\left(2 \mathrm{H}, \mathrm{t}, J=6.6, \mathrm{CH}_{2}-\mathrm{Br}\right), 2.14-2.03\left(2 \mathrm{H}, \mathrm{m},-\mathrm{CH}_{2}-\right), 2.00-$ $1.90\left(2 \mathrm{H}, \mathrm{m},-\mathrm{CH}_{2^{-}}\right), 1.33\left(9 \mathrm{H}, \mathrm{s},-\mathrm{C}\left(\mathrm{CH}_{3}\right)_{3}\right)$.

Compound 4: (40\%). $\mathrm{C}_{32} \mathrm{H}_{36} \mathrm{OPBr} \quad \mathrm{M}=547.52 \mathrm{~g} / \mathrm{mole} \delta_{\mathrm{H}}\left(300 \mathrm{MHz}, \mathrm{CDCl}_{3}\right)$ 7.86-7.72 $(9 \mathrm{H}, \mathrm{m}, \mathrm{P}-\mathrm{Ar}-H), 7.69-7.58(6 \mathrm{H}, \mathrm{m}, \mathrm{P}-\mathrm{Ar}-H), 7.23(2 \mathrm{H}, \mathrm{d}, J=8.8 \mathrm{~Hz}, \operatorname{Ar}-H), 6.72(2 \mathrm{H}$, 
$\mathrm{d}, J=8.8 \mathrm{~Hz}, \mathrm{H}-\mathrm{Ar}), 4.01\left(2 \mathrm{H}, \mathrm{t}, J=5.8, \mathrm{Ar}-\mathrm{O}-\mathrm{CH}_{2}\right), 3.93-3.80\left(2 \mathrm{H}, \mathrm{m},-\mathrm{CH}_{2}-\mathrm{P}\right), 2.21-$

$2.12\left(2 \mathrm{H}, \mathrm{m},-\mathrm{CH}_{2^{-}}\right), 1.92-1.81\left(2 \mathrm{H}, \mathrm{m},-\mathrm{CH}_{2^{-}}\right), 1.25\left(9 \mathrm{H}, \mathrm{s},-\mathrm{C}\left(\mathrm{CH}_{3}\right)_{3}\right)$.

\section{Stability constant determination}

The procedures and experimental conditions were the same in both solvents methanol and acetonitrile, except the nature of the background electrolyte used to maintain the ionic strength constant at $0.01 \mathrm{M}$, which was $\mathrm{NaBr}$ in methanol and $\mathrm{Et}_{4} \mathrm{NBr}$ in acetonitrile. Small volumes $(0.05 \mathrm{ml})$ of the salt solution were added to $2 \mathrm{ml}$ of the ligand solution directly in the spectrophotometric cell thermoregulated at $25^{\circ} \mathrm{C}$. For each volume added, the spectrum of the solution was recorded on a Cary 3 spectrophotometer (Varian) between 250 and $300 \mathrm{~nm}$. This method, previously used to study cation complexation, is described in details in ref. 25. At least three independent experiments have been performed. The interpretation of the spectra using the program Specfit ${ }^{26}$ led to the determination of the concentration ratio $\beta_{\mathrm{x} 1}=$ $\left[\mathrm{A}_{\mathrm{x}} \mathrm{L}^{4-\mathrm{xn}}\right] /\left(\left[\mathrm{A}^{\mathrm{n}-}\right]^{\mathrm{x}}\left[\mathrm{L}^{4+}\right]\right)\left(\right.$ where $\mathrm{A}^{\mathrm{n}-}$ is the anion and $\mathrm{L}^{4+}$ the ligand).

\section{Ion selective membrane electrodes (ISE)}

The membranes were prepared by dissolving $4 \mathrm{mg}$ of the ionophore 2 or $4,60 \mathrm{mg}$ of PVC, $120 \mathrm{mg}$ of plasticizer (o-NPOE), about $184 \mathrm{mg}$ in total, in $1.5 \mathrm{~mL}$ of dried and distilled THF. Each solution was poured into a glass ring ( $24 \mathrm{~mm}$ in diameter). After slow evaporation of the solvent overnight, several membranes of $7 \mathrm{~mm}$ diameter were cut from each mother membrane and incorporated into $\mathrm{Ag} / \mathrm{AgCl}$ Philips electrodes bodies of IS 561 type (Moeller S.A., Zurich). Three identical electrodes were always studied. ${ }^{27}$ The EMF measurements were carried out at $20^{\circ} \mathrm{C}$ using 
Lawson Lab 16 EMF, multi-channel voltmeter or in some cases using Metrohm 654 voltmeter. A double-junction reference Radelkis 0P0820P electrode with 1M $\mathrm{CH}_{3} \mathrm{COOLi}$ solution in the bridge cell was used. The measurements were carried out using the cells of the type:

$\mathrm{Ag}|\mathrm{AgCl}| 1 \mathrm{M} \mathrm{KCl}\left|1 \mathrm{M} \mathrm{CH} \mathrm{CH}_{3} \mathrm{COOLi}\right|$ sample $\|$ membrane || $0.05 \mathrm{M} \mathrm{MES/NaOH}$, $0.01 \mathrm{M} \mathrm{NaCl}|\mathrm{AgCl}| \mathrm{Ag}$.

The calibration curves were obtained by addition of standard solutions of different anions to $50 \mathrm{ml}$ of $0.01 \mathrm{M} \mathrm{NaCl}$ in $0.05 \mathrm{M} \mathrm{MES} / \mathrm{NaOH}$ buffer solution of $\mathrm{pH}=5.5$. They were also measured by successive dilution of initial $5 \times 10^{-2} \mathrm{M}$ salt solutions until further dilution resulted in no potential change. Potentiometric sensitivity to $\mathrm{ClO}_{4}{ }^{-}$anions was studied also by calibration of the membrane electrodes (PVC/oNPOE/2) in pure $\mathrm{NaClO}_{4}$ water solution. Potentiometric selectivity coefficients $\left(\log K^{\text {pot }}{ }_{\mathrm{ClO}, J}\right)$ were determined by the Separate Solution Method $(\mathrm{SSM})^{28}$ and were calculated (equation 1), by using the EMF values for the measured ion activities $a_{I}$ at the concentration $10^{-2} \mathrm{M}$ :

$$
\log K_{I, J}^{p o t}=\frac{\left(E_{J}-E_{I}\right) z_{I} F}{2.303 R T}+\left(1-\frac{z_{I}}{z_{J}}\right) \log a_{I}
$$

In equation (1), I and $J$ correspond to the primary and the interfering anions, respectively. The values of $\log K^{\text {pot }}{ }_{\mathrm{ClO}, J}$ were derived from measurements performed with perchorate as primary anion, i.e. the best complexed anion, $J$ referring to the other studied anions. 
Potentiometric selectivity coefficients $\left(\log K_{I, \mathrm{Cl}}^{p o t}\right)$ were also determined by the Fix Interference Method (FIM). ${ }^{28}$ The concentration of $\mathrm{NaCl}$ in each measured anion solution was $10 \mathrm{mM}$. Values of $\log K_{I, \mathrm{Cl}}^{\text {pot }}$ were determined using chloride as interfering anion and in this case, $I$ corresponds to the other anions.

\section{RESULTS AND DISCUSSION}

The tetra (triphenylphosphonium) p-tert-butylcalix[4]arene 2 has been obtained in $30 \%$ yield by refluxing in chloroform the tetrabromobutoxycalix[4]arene $\mathbf{1}$ in presence of 20 equivalents of triphenylphosphine during 6 days as represented in Scheme 1. The tetrabromocalix[4]arene 1 was prepared by reacting the p-tertbutylcalix[4]arene in $\mathrm{DMF}$ at $80^{\circ} \mathrm{C}$ during 4 days with 1,4-dibromobutane in the presence of sodium hydride. This compound adopts the cone conformation as shown by the presence in its ${ }^{1} \mathrm{H}$ NMR spectrum of an $\mathrm{AB}$ system at 4.36 and $3.15 \mathrm{ppm}$. The monomeric unit 4 was obtained according to the same procedure in $40 \%$ yield (Scheme 2).

Figure 1.

The affinity of ligand 2 for a series of anions of different charge, size and geometry: $\mathrm{I}^{-}, \mathrm{NO}_{3}{ }^{-}, \mathrm{SCN}^{-}, \mathrm{ClO}_{4}{ }^{-}, \mathrm{SO}_{4}{ }^{2-}, \mathrm{S}_{2} \mathrm{O}_{3}{ }^{2-}, \mathrm{CrO}_{4}{ }^{2-}, \mathrm{MoO}_{4}{ }^{2-}, \mathrm{Cr}_{2} \mathrm{O}_{7}{ }^{2-}$ has been studied using two approaches. A first assessment of the complexation was obtained using ${ }^{1} \mathrm{H}$ and ${ }^{31} \mathrm{P}$ NMR spectroscopy coupled with solid/liquid extraction. Among the anions tested only $\mathrm{ClO}_{4}{ }^{-} \mathrm{I}^{-}$and $\mathrm{SCN}^{-}$led to modifications of the signals of the ligand in $\mathrm{CDCl}_{3}$ after equilibration with an excess of 6 equivalents of the solid 
sodium salts (Table 1). These three anions are all of different geometry, and they are lipophilic. ${ }^{29}$ They might exchange with bromide anions of the ligand because of their higher lipophilicity.

Fig. 1 shows the ${ }^{1} \mathrm{H}$ NMR spectra of 2 alone and in presence of perchlorate ions.

Table 1 Most important changes $\Delta(\delta)$ in the proton ${ }^{\mathrm{a}}$ chemical shifts $(\delta)[\mathrm{ppm}]$ experienced by 2 in presence of $\mathrm{I}, \mathrm{SCN}^{-}$and $\mathrm{ClO}_{4}{ }^{-}$anions in $\mathrm{CDCl}_{3}$

\begin{tabular}{cccccc}
\hline & $\mathrm{c}$ & $\mathrm{e}$ & $\mathrm{f}$ & $\mathrm{g}$ & $\mathrm{j}$ \\
\hline$\delta(\mathbf{2})$ & 6.63 & 2.91 & 4.23 & 3.87 & 3.94 \\
$\delta(\mathbf{2}+\mathrm{NaI})$ & 6.93 & 3.35 & 4.42 & 4.40 & 4.00 \\
$\Delta(\delta)$ & 0.30 & 0.44 & 0.19 & 0.53 & -0.06 \\
$\delta(\mathbf{2}+\mathrm{NaSCN})$ & 6.95 & 3.33 & 4.39 & 4.27 & 3.76 \\
$\Delta(\delta)$ & 0.32 & 0.42 & 0.16 & 0.40 & -0.18 \\
$\delta\left(\mathbf{2}+\mathrm{NaClO}_{4}\right)$ & 6.95 & 3.35 & 4.40 & 4.27 & 3.47 \\
$\Delta(\delta)$ & 0.32 & 0.44 & 0.17 & 0.40 & -0.47 \\
\hline
\end{tabular}

${ }^{a}$ for the attribution of the protons see Fig. 1.

The important changes (expressed as $\Delta(\delta)$ ) were observed for the $\mathrm{CH}_{2}$ protons adjacent to the phenolic oxygen atoms (g atoms) and for the $\mathrm{CH}_{2}$ protons adjacent to the phosphorus atoms ( $\mathrm{j}$ atoms). They correspond to a multiplet from 4.01 to 3.78 ppm which undergoes shifts and gives two multiplets from 4.32 to $4.23 \mathrm{ppm}$ for the $\mathrm{g}$ atoms and from 3.56 to 3.42 for the $\mathrm{j}$ atoms. The signals corresponding to the $\mathrm{AB}$ system (f,e atoms) at 4.23 and $2.91 \mathrm{ppm}$ in $\mathbf{2}$ are also shifted to give another $\mathrm{AB}$ system at 4.40 and $3.35 \mathrm{ppm}$ in the presence of perchlorate anion. An important shift of the signal corresponding to the aromatic protons (c atoms) is also observed (Table 1). These changes clearly indicate strongest interaction of ligand with perchlorate, which is further confirmed by ${ }^{31} \mathrm{P}$ NMR. The signal of the phosphorus atoms at $25.74 \mathrm{ppm}$ in the free ligand is shifted to $24.76 \mathrm{ppm}$ in the presence of perchlorate ions. In the case of iodide and thiocyanate, the signal of the phosphorus atoms is 
shifted to 25.55 and $24.99 \mathrm{ppm}$, respectively. These changes, in agreement with the ${ }^{1} \mathrm{H}$ NMR spectra, suggest significant interactions between these anions and the ligand. No change was observed in the ${ }^{1} \mathrm{H}$ NMR spectra of the phosphonium monomer 4 in the presence of perchlorate anion.

Table 2 Most important changes $\Delta(\delta)$ in the proton ${ }^{\mathrm{a}}$ chemical shifts $(\delta)[\mathrm{ppm}]$ experienced by 2 in presence of different perchlorate salts in $\mathrm{CD}_{3} \mathrm{CN}$.

\begin{tabular}{cccccc}
\hline & $\mathrm{c}$ & $\mathrm{e}$ & $\mathrm{f}$ & $\mathrm{g}$ & $\mathrm{j}$ \\
\hline$\delta(\mathbf{2})$ & 6.87 & 2.93 & 4.15 & 3.74 & 3.81 \\
$\delta\left(\mathbf{2}+\mathrm{LiClO}_{4}\right)$ & 7.19 & 3.28 & 4.21 & 4.36 & 3.29 \\
$\Delta(\delta)$ & 0.32 & 0.35 & 0.06 & 0.62 & -0.52 \\
$\delta\left(\mathbf{2}+\mathrm{NaClO}_{4}\right)$ & 7.22 & 3.33 & 4.21 & 4.09 & 3.28 \\
$\Delta(\delta)$ & 0.35 & 0.40 & 0.06 & 0.35 & -0.53 \\
$\delta(\mathbf{2}+\mathrm{CsClO}$ & \\
$\Delta(\delta)$ & 6.86 & 2.92 & 4.14 & 3.75 & 3.75 \\
\hline
\end{tabular}

${ }^{a}$ for the attribution of the protons see Fig. 1.

The ${ }^{1} \mathrm{H}$ NMR experiments were repeated in deutered acetonitrile with perchlorate salts of different alkali metals. The spectra of the ligand are very similar in both solvents. The presence of $\mathrm{NaClO}_{4}$ induces shifts of the same signals as in $\mathrm{CDCl}_{3}$. With $\mathrm{LiClO}_{4}$, the signal of methylene protons adjacent to the phenolic oxygen atoms (protons g) shifts from 3.74 to $4.36 \mathrm{ppm}$. This shift is larger than that observed in the presence of $\mathrm{NaClO}_{4}$. With both salts the shifts corresponding to the signals of the j protons next to the $\mathrm{P}$ atoms (which are supposed to interact with perchlorate) are similar. With $\mathrm{CsClO}_{4}$, the only shift observed is that for the $\mathrm{j}$ protons, but the value is very small in comparison to the effect of the other salts $\left(-0.06 \mathrm{ppm}\right.$ with $\mathrm{CsClO}_{4}$, -0.52 with $\mathrm{LiClO}_{4}$ and -0.53 with $\mathrm{NaClO}_{4}$ ). The changes observed suggest that ligand/anion interaction is connected with the nature of the counter ion and its affinity to the ligand. 
The complexation has also been followed by UV absorption spectrophotometry in methanol and acetonitrile. No changes were observed in the spectrum of the ligand upon addition of the anions (introduced as their sodium salts) in methanol. However, in acetonitrile, significant modifications of the spectra appeared in the presence of perchlorate, thiocyanate and iodide anions, i.e. the same anions for which shifts were noticed in NMR spectroscopy. These changes were interpreted using program Specfit $^{26}$ by the formation of 1:1 (anion:ligand) complexes with sodium perchlorate $\left(\log \beta_{11}=3.81 \pm 0.02\right)$ and with lithium perchlorate $\left(\log \beta_{11}=3.71 \pm 0.04\right)$. Changes in presence of sodium thiocyanate were interpreted by the formation of 2:1 complex $\left(\log \beta_{21}=8.7 \pm 0.3\right)$. The different structures of the two anions (tetrahedral for perchlorate and linear for thiocyanate) may account for the difference in the stoichiometries of the complexes. The strong absorption of iodide precluded any interpretation of the spectra. In case of the other anions studied in this solvent, the very small spectral variations observed suggest only weak anion interactions with ligand 2.

Table 3 Characteristics of the electrode potentiometric response towards chosen primary anions in the presence of $10 \mathrm{mM} \mathrm{NaCl}$. Electrodes with PVC/o-NPOE (1/2) membrane containing 2\% wt. of 2 or 4.

\begin{tabular}{|c|c|c|c|}
\hline $\begin{array}{l}\text { Ligand, } \\
\text { Inner and conditioning electrolyte }\end{array}$ & $\begin{array}{c}\text { Primary } \\
\text { anion }\end{array}$ & $\begin{array}{c}\mathrm{DL}^{\mathrm{a}} \\
(\log a)\end{array}$ & $\begin{array}{r}\text { Slope } \\
(\mathrm{mV})\end{array}$ \\
\hline (2), $\mathrm{MES} / \mathrm{NaOH} / 10^{-2} \mathrm{M} \mathrm{NaCl}(\mathrm{pH}=5.5)$ & $\mathrm{ClO}_{4}^{-}$ & -7.0 & -58 \\
\hline (2), Water solution & $\mathrm{ClO}_{4}^{-}$ & -5.5 & -55 \\
\hline (2), $\mathrm{MES} / \mathrm{NaOH} / 10^{-2} \mathrm{M} \mathrm{NaCl}(\mathrm{pH}=5.5)$ & $\mathrm{SCN}^{-}$ & -6.0 & -55 \\
\hline (2), $\mathrm{MES} / \mathrm{NaOH} / 10^{-2} \mathrm{M} \mathrm{NaCl}(\mathrm{pH}=5.5)$ & $\mathrm{I}^{-}$ & -6.0 & -52 \\
\hline (2), $\mathrm{MES} / \mathrm{NaOH} / 10^{-2} \mathrm{M} \mathrm{NaCl}(\mathrm{pH}=5.5)$ & $\mathrm{NO}_{3}^{-}$ & -5.0 & -51 \\
\hline (2), $\mathrm{MES} / \mathrm{NaOH} / 10^{-2} \mathrm{M} \mathrm{NaCl}(\mathrm{pH}=5.5)$ & $\mathrm{Br}^{-}$ & -4.0 & -44 \\
\hline
\end{tabular}




\begin{tabular}{lccc}
\hline (2), $\mathrm{MES} / \mathrm{NaOH} / 10^{-2} \mathrm{M} \mathrm{NaCl}(\mathrm{pH}=5.5)$ & $\mathrm{Cr}_{2} \mathrm{O}_{7}^{2-}$ & -5.5 & -47 \\
(4), $\mathrm{MES} / \mathrm{NaOH} / 10^{-2} \mathrm{M} \mathrm{NaCl}(\mathrm{pH}=5.5)$ & $\mathrm{ClO}_{4}^{-}$ & -6.0 & -49 \\
\hline
\end{tabular}

${ }^{a}$ DL: detection limit.

Ligand 2 was applied as new sensing material in ion-selective PVC membrane electrodes (ISEs). The potentiometric response towards the same anions, including also chloride, bromide, phosphate, hydrogenophosphate, carbonate, acetate, oxalate, citrate and benzoate anions was studied using two different plasticizers: BEHS and o-NPOE in the electrode membranes. Only the membranes containing o-NPOE were stable and long lasting, so only this plasticizer was chosen for further studies. Several PVC/o-NPOE membranes were prepared but the membrane without any additives (anionic $^{21,30,31}$ or cationic ${ }^{17,32}$ sites) was the best choice. The composition of the membrane was the following: PVC/o-NPOE (1/2) containing $2 \%$ wt of ionophore $\mathbf{2}$ or $\mathbf{4}$. Electrodes were calibrated using buffer solution (2morpholino)ethanesulfonic acid monohydrate (MES)-NaOH $(\mathrm{pH}=5.5)$ containing sodium salts of anions. The ionic strength was adjusted with $10 \mathrm{mM} \mathrm{NaCl}$. Sensing properties of the membrane electrode are presented in Fig. 2. and are summarised in Table 3.

Table 4 Selectivity coefficients, $\log K_{I, J}^{\text {pot }}$ of electrodes containing ligand $\mathbf{2}$ or $\mathbf{4}$, determined in buffered $(\mathrm{pH}=5.5)$ and unbuffered $(\mathrm{pH}=6.5$ or 6.0$)$ sodium salts solutions by FIM or SSM.

\begin{tabular}{ccccccccc}
$\begin{array}{c}\text { Ligand/ } \\
\text { Method }\end{array}$ & $\mathrm{pH}$ & $\mathrm{ClO}_{4}^{-}$ & $\mathrm{SCN}^{-}$ & $\mathrm{I}^{-}$ & $\mathrm{NO}_{3}^{-}$ & $\mathrm{Br}^{-}$ & $\mathrm{Cl}^{-}$ & $\mathrm{Cr}_{2} \mathrm{O}_{7}^{2-}$ \\
\hline 2/FIM & 5.5 & 0 & -1.2 & -1.8 & -2.6 & -3.0 & $<-4.0$ & - \\
$\mathbf{2} / \mathrm{SSM}$ & 5.5 & 0 & -1.3 & -2.0 & -2.9 & -4.0 & $<-4.0$ & -1.9 \\
$\mathbf{2} / \mathrm{SSM}$ & 6.5 & 0 & -1.4 & -1.9 & -3.1 & -3.5 & $<-4.0$ & -1.8 \\
$\mathbf{2} / \mathrm{FIM}$ & 6.0 & 0 & -1.7 & -2.3 & -2.4 & -3.0 & -4.1 & - \\
$\mathbf{4} / \mathrm{SSM}$ & 5.5 & 0 & -1.1 & -1.6 & -2.5 & -3.5 & $<-4.0$ & -1.9
\end{tabular}


The electrodes showed Nernstian response and highest selectivity for $\mathrm{ClO}_{4}{ }^{-}$ions in buffered solution $(\mathrm{pH}=5.5)$ and in water $(\mathrm{pH}=6.5)$. They also showed close to Nernstian response to $\mathrm{I}^{-}, \mathrm{NO}_{3}{ }^{-}, \mathrm{SCN}^{-}$. There was no significant reaction for $\mathrm{SO}_{4}{ }^{2-}$, $\mathrm{CO}_{3}{ }^{2-}, \mathrm{HPO}_{4}{ }^{2-}, \mathrm{PO}_{4}{ }^{3-}$, citrate, acetate, benzoate and oxalate. Rather quick (within $15-$ 20 s) and stable response of the electrodes was observed during the measurements and the answer was fully reversible. The lifetime of electrode with ionophore 2 is more than three weeks. Selectivity coefficients $K^{\text {pot }}{ }_{\mathrm{ClO}, J}$ measured by the separate solution method $(\mathrm{SSM})^{28}$ in $10 \mathrm{mM}$ buffered $(\mathrm{pH}=5.5)$ or $100 \mathrm{mM}$ unbuffered $(\mathrm{pH}=6.5)$ solutions of the corresponding sodium salts are given in Table 4. Ligand 2 provides the following selectivity order: $\mathrm{ClO}_{4}{ }^{-}>\mathrm{SCN}^{-}>\mathrm{I}^{-}>\mathrm{Cr}_{2} \mathrm{O}_{7}{ }^{2-}>\mathrm{NO}_{3}^{-}>$ $\mathrm{Br}^{-}>\mathrm{Cl}^{-}$, which is quite similar to the Hofmeister series observed for the typical ion exchanger, tetradodecylammonium tetrakis(4-chlorophenyl)borate (TDMACl). ${ }^{3,18,33}$ The selectivity pattern of electrodes containing the phosphonium monomer $\mathbf{4}$ is similar. However the slope and linear range are not as good as the coresponding values for the electrodes with compound 2.

Figure 2.

\section{CONCLUSION}

We have synthesised a new tetra(triphenylphosphonium) $p$-tert-butylcalix[4]arene in the cone conformation. As shown by ${ }^{1} \mathrm{H}$ and ${ }^{31} \mathrm{P}$ NMR and UV spectrophotometry, the compound proved to interact selectively with some anions, namely $\mathrm{ClO}_{4}{ }^{-}, \mathrm{SCN}^{-}$, 
and $\mathrm{I}^{-}$. This interaction appeared to be dependent on the nature of the alkali counter ion. This compound has also been incorporated in PVC-membrane electrodes as ionophore-sensing material for anions. The following selectivity order was found: $\mathrm{ClO}_{4}^{-}>\mathrm{SCN}_{6}^{-}>\mathrm{I}^{-}>\mathrm{Cr}_{2} \mathrm{O}_{7}^{2-}>\mathrm{NO}_{3}^{-}>\mathrm{Br}^{-}>\mathrm{Cl}^{-}$which is similar to the Hofmeister series observed for typical ion exchangers. However the performances of such electrodes are much better than the electrodes with the corresponding monomeric subunit. These results suggest that the interaction between the ligand and the anions may be a combination of electrostatic contribution and complementarity between the cavity formed by the phosphonium groups attached to the calixarene and the anion. Structural variations around this molecule, as for instance those concerning the nature of the substituents on the functional groups, are currently examined in order to optimise these selectivities.

\section{Acknowledgements}

R.P. gratefully acknowledges Gdansk University of Technology, Poland, and the Ministère de la Recherche et des Nouvelles Technologies, France (Cotutelles de thèses), for financial support.

\section{References}

1. Beer, P.D.; Hayes, E. Coord. Chem. Rev. 2003, 240, 167.

2. Sessler, J.L.; Sansom, P.I.; Andrievsky, A.; Kral, V. in Supramolecular Chemistry of Anions, Bianchi, A., Bowman-James, K., Garcia-Espana, E., Eds.; John Wiley-VCH: New York, 1997; ch. 10, p. 355. 
3. Bakker, E.; Buhlmann, P.; Pretsch, E. Chem. Rev. 1997, 97, 3124.

4. Buhlmann, P.; Pretsch, E.; Bakker, E. Chem. Rev. 1998, 98, 1593.

5. Beer, P.D.; Gale, P.A. Angew. Chem. Int. Ed. 2001, 40, 486.

6. Amemiya, S.; Buhlmann, P.; Umezawa, Y.; Jagessar, R.C.; Burns, D.H. Anal. Chem. 1999, 71, 1049.

7. Schmidtchen, F. P.; Berger, M. Chem. Rev. 1997, 97, 1609.

8. Beer, P.D.; Cadman, J. Coord. Chem. Rev. 2000, 205, 31.

See also Gale, P.A. Coord. Chem. Rev. 2001, 213, 79; Gale, P.A. Coord. Chem. Rev. 2003, 240, 191.

9. Matthews, S.E.; Beer, P.D. in Calixarenes 2001; Asfari, Z., Böhmer, V., Harrowfield, J., Vicens, J., Eds.; Kluwer Academic: Dordrecht, 2001; ch. 23, p. 421.

10. Falana, O.M.; Koch, H.F.; Roundhill, D.M.; Lumetta, G.J.; Hay, B.P. Chem. Commun. 1998, 503.

11. Cameron, B.R.; Loeb, S. Chem. Commun. 1997, 573.

12. Nam, K.C.; Chun, J.C.; Kang, S.O.; Ko, S.W. Bull. Korean Chem. Soc. 1999, 20, 1108.

13. Scheerder, J.; Fochi, M.; Engbersen, J.F.J.; Reinhoudt, D.N. J. Org. Chem. 1994, $59,7815$.

14. Scheerder, J.; Engbersen, J.F.J.; Casnati, A.; Ungaro, R.; Reinhoudt, D.N. J. Org. Chem. 1995, 60, 6448.

15. Georgiev, E.M.; Wolf, N.; Roundhill, D.M. Polyhedron 1997, 16, 1581.

16. Beer, P.D.; Drew, M.G.B.; Gradwell, K. J. Chem. Soc. Perkin Trans. 2 2000, 511.

17. Wróblewski, W.; Brzózka, Z.; Rudkevich, D.M.; Reinhoudt, D.N. Sensors \& Actuators B 1996, 37, 151. 
18. Rudkevich, D.M.; Verboom, W.; Reinhoudt, D.N. Tetrahedron Lett. 1994, 35, 7131.

19. Rudkevich, D.M.; Verboom, W.; Reinhoudt, D.N. J. Org. Chem. 1994, 59, 3683.

20. Malinowska, E.; Niedziolka, J.; Meyerhoff, M.E. Anal. Chim. Acta 2001, 432, 67.

21. Malinowska, E.; Gorski, L.; Meyerhoff, M.E. Anal. Chim. Acta 2002, 468, 133.

22. Maeda, H.; Osuka, A.; Furuta, H. J. Incl. Phenom. 2004, 49, 33.

23. Pomecko, R.; Asfari, Z.; Hubscher-Bruder, V.; Arnaud-Neu, F.; Vicens, J.; Bochenska, M. XXVIIIth International Symposium on Macrocylic Chemistry, Gdansk University of Technology, Gdansk, Poland, 13-18 July 2003.

24. Hamdi, A.; Nam, K.C.; Ryu, B.J.; Kim, J.S.; Vicens, J. Tetrahedron Lett. 2004, 45, 4689.

25. Arnaud-Neu, F.; Collins, E.M.; Deasy, M.; Ferguson, G.; Harris, S.J.; Kaitner, B.; Lough, A.J.; McKervey, M.A.; Marques, E.; Ruhl, B.L.; Schwing-Weill, M.J.; Seward, E.M. J. Am. Chem. Soc. 1989, 111, 8681.

26. Gampp, H.; Maeder, M.; Meyer, C.J.; Zuberbühler, A.D. Talanta 1986, 33, 943.

27. Bochenska, M.; Zielinska, A.; Pomecko, R.; Hubscher-Bruder, V.; Arnaud-Neu, F. J. Incl. Phenom. 2005, 52, 129.

28. Umezawa, Y.; Buhlmann, P.; Umezawa, K.; Tohda, K.; Amemiya, S. Pure Appl. Chem. 2000, 72, 1851, see also Umezawa, Y.; Buhlmann, P.; Umezawa, K.; Hamada, N.; Aoki, H. Pure Appl. Chem. 2002, 74, 923.

29. Moyer, B.A.; Bonnesen, P.V. in Supramolecular Chemistry of Anions, Bianchi, A., Bowman-James, K., Garcia-Espana, E., Eds.; John Wiley-VCH: New York, 1997; ch. 1, p. 1.

30. Schaller, U.; Bakker, E.; Spichiger, U.E.; Pretsch, E. Anal. Chem., 1994, 66, 391. 31. Bakker, E.; Malinowska, E.; Schiller, R.D.; Meyerhoff, M.E. Talanta 1994, 41, 881. 

2000, 72, 1618.

33. Egorov, V.V.; Rakhmanko, E.M.; Okaev, E.; Nazarov, V.; Pomelyenok, E.; Pavlova, T. Electroanalysis 2004, 16, 1459. 
Figure Captions

Figure 1.

Changes in ${ }^{1} \mathrm{H}$ NMR spectra of 2 in presence of $\mathrm{ClO}_{4}{ }^{-}$anion .

Figure 2.

Potentiometric responses of electrode with ligand 2 to anions in $\mathrm{MES} / \mathrm{NaOH}$ buffer $(\mathrm{pH}=5.5)$ and ionic strength adjusted with $10 \mathrm{mM} \mathrm{NaCl}$ solution.

URL: http:/mc.manuscriptcentral.com/tandf/gsch Email: suprachem@mail.cm.utexas.edu 
Table 1

Table 1 Most important changes $\Delta(\delta)$ in the proton ${ }^{\mathrm{a}}$ chemical shifts $(\delta)[\mathrm{ppm}]$ experienced by 2 in presence of $\mathrm{I}^{-}, \mathrm{SCN}^{-}$and $\mathrm{ClO}_{4}{ }^{-}$anions in $\mathrm{CDCl}_{3}$

\begin{tabular}{cccccc}
\hline & $\mathrm{c}$ & $\mathrm{e}$ & $\mathrm{f}$ & $\mathrm{g}$ & $\mathrm{j}$ \\
\hline$\delta(\mathbf{2})$ & 6.63 & 2.91 & 4.23 & 3.87 & 3.94 \\
$\delta(\mathbf{2}+\mathrm{NaI})$ & 6.93 & 3.35 & 4.42 & 4.40 & 4.00 \\
$\Delta(\delta)$ & 0.30 & 0.44 & 0.19 & 0.53 & -0.06 \\
$\delta(\mathbf{2}+\mathrm{NaSCN})$ & 6.95 & 3.33 & 4.39 & 4.27 & 3.76 \\
$\Delta(\delta)$ & 0.32 & 0.42 & 0.16 & 0.40 & -0.18 \\
$\delta\left(\mathbf{2}+\mathrm{NaClO}_{4}\right)$ & 6.95 & 3.35 & 4.40 & 4.27 & 3.47 \\
$\Delta(\delta)$ & 0.32 & 0.44 & 0.17 & 0.40 & -0.47 \\
\hline
\end{tabular}

${ }^{a}$ for the attribution of the protons see Fig. 1.

Table 2

Table 2 Most important changes $\Delta(\delta)$ in the proton ${ }^{\mathrm{a}}$ chemical shifts $(\delta)[\mathrm{ppm}]$ experienced by 2 in presence of different perchlorate salts in $\mathrm{CD}_{3} \mathrm{CN}$.

\begin{tabular}{cccccc}
\hline & $\mathrm{c}$ & $\mathrm{e}$ & $\mathrm{f}$ & $\mathrm{g}$ & $\mathrm{j}$ \\
\hline$\delta(\mathbf{2})$ & 6.87 & 2.93 & 4.15 & 3.74 & 3.81 \\
$\delta\left(\mathbf{2}+\mathrm{LiClO}_{4}\right)$ & 7.19 & 3.28 & 4.21 & 4.36 & 3.29 \\
$\Delta(\delta)$ & 0.32 & 0.35 & 0.06 & 0.62 & -0.52 \\
$\delta\left(\mathbf{2}+\mathrm{NaClO}_{4}\right)$ & 7.22 & 3.33 & 4.21 & 4.09 & 3.28 \\
$\Delta(\delta)$ & 0.35 & 0.40 & 0.06 & 0.35 & -0.53 \\
$\delta\left(\mathbf{2}+\mathrm{CsClO}_{4}\right)$ & 6.86 & 2.92 & 4.14 & 3.75 & 3.75 \\
$\Delta(\delta)$ & -0.01 & -0.01 & -0.01 & 0.01 & -0.06 \\
\hline
\end{tabular}

${ }^{a}$ for the attribution of the protons see Fig. 1. 
Table 3

Table 3 Characteristics of the electrode potentiometric response towards chosen primary anions in the presence of $10 \mathrm{mM} \mathrm{NaCl}$. Electrodes with PVC/o-NPOE (1/2) membrane containing 2\% wt. of 2 or 4.

\begin{tabular}{|c|c|c|c|}
\hline $\begin{array}{l}\text { Ligand, } \\
\text { Inner and conditioning electrolyte }\end{array}$ & $\begin{array}{l}\text { Primary } \\
\text { anion }\end{array}$ & $\begin{array}{c}\mathrm{DL}^{\mathrm{a}} \\
(\log a)\end{array}$ & $\begin{array}{l}\text { Slope } \\
(\mathrm{mV})\end{array}$ \\
\hline (2), $\mathrm{MES} / \mathrm{NaOH} / 10^{-2} \mathrm{M} \mathrm{NaCl}(\mathrm{pH}=5.5)$ & $\mathrm{ClO}_{4}^{-}$ & -7.0 & -58 \\
\hline (2), Water solution & $\mathrm{ClO}_{4}^{-}$ & -5.5 & -55 \\
\hline (2), $\mathrm{MES} / \mathrm{NaOH} / 10^{-2} \mathrm{M} \mathrm{NaCl}(\mathrm{pH}=5.5)$ & $\mathrm{SCN}^{-}$ & -6.0 & -55 \\
\hline (2), $\mathrm{MES} / \mathrm{NaOH} / 10^{-2} \mathrm{M} \mathrm{NaCl}(\mathrm{pH}=5.5)$ & $\mathrm{I}^{-}$ & -6.0 & -52 \\
\hline (2), $\mathrm{MES} / \mathrm{NaOH} / 10^{-2} \mathrm{M} \mathrm{NaCl}(\mathrm{pH}=5.5)$ & $\mathrm{NO}_{3}^{-}$ & -5.0 & -51 \\
\hline (2), $\mathrm{MES} / \mathrm{NaOH} / 10^{-2} \mathrm{M} \mathrm{NaCl}(\mathrm{pH}=5.5)$ & $\mathrm{Br}^{-}$ & -4.0 & -44 \\
\hline (2), $\mathrm{MES} / \mathrm{NaOH} / 10^{-2} \mathrm{M} \mathrm{NaCl}(\mathrm{pH}=5.5)$ & $\mathrm{Cr}_{2} \mathrm{O}_{7}^{2-}$ & -5.5 & -47 \\
\hline (4), $\mathrm{MES} / \mathrm{NaOH} / 10^{-2} \mathrm{M} \mathrm{NaCl}(\mathrm{pH}=5.5)$ & $\mathrm{ClO}_{4}^{-}$ & -6.0 & -49 \\
\hline
\end{tabular}

${ }^{a}$ DL: detection limit.

Table 4

Table 4 Selectivity coefficients, $\log K_{I, J}^{\text {pot }}$ of electrodes containing ligand $\mathbf{2}$ or $\mathbf{4}$, determined in buffered $(\mathrm{pH}=5.5)$ and unbuffered $(\mathrm{pH}=6.5$ or 6.0$)$ sodium salts solutions by FIM or SSM.

\begin{tabular}{ccccccccc}
$\begin{array}{c}\text { Ligand/M } \\
\text { ethod }\end{array}$ & $\mathrm{pH}$ & $\mathrm{ClO}_{4}^{-}$ & $\mathrm{SCN}^{-}$ & $\mathrm{I}^{-}$ & $\mathrm{NO}_{3}^{-}$ & $\mathrm{Br}^{-}$ & $\mathrm{Cl}^{-}$ & $\mathrm{Cr}_{2} \mathrm{O}_{7}^{2-}$ \\
\hline 2/FIM & 5.5 & 0 & -1.2 & -1.8 & -2.6 & -3.0 & $<-4.0$ & - \\
$\mathbf{2 / S S M}$ & 5.5 & 0 & -1.3 & -2.0 & -2.9 & -4.0 & $<-4.0$ & -1.9 \\
$\mathbf{2} / \mathrm{SSM}$ & 6.5 & 0 & -1.4 & -1.9 & -3.1 & -3.5 & $<-4.0$ & -1.8 \\
$\mathbf{2} / \mathrm{FIM}$ & 6.0 & 0 & -1.7 & -2.3 & -2.4 & -3.0 & -4.1 & - \\
$\mathbf{4} / \mathrm{SSM}$ & 5.5 & 0 & -1.1 & -1.6 & -2.5 & -3.5 & $<-4.0$ & -1.9 \\
\hline
\end{tabular}


Scheme 1

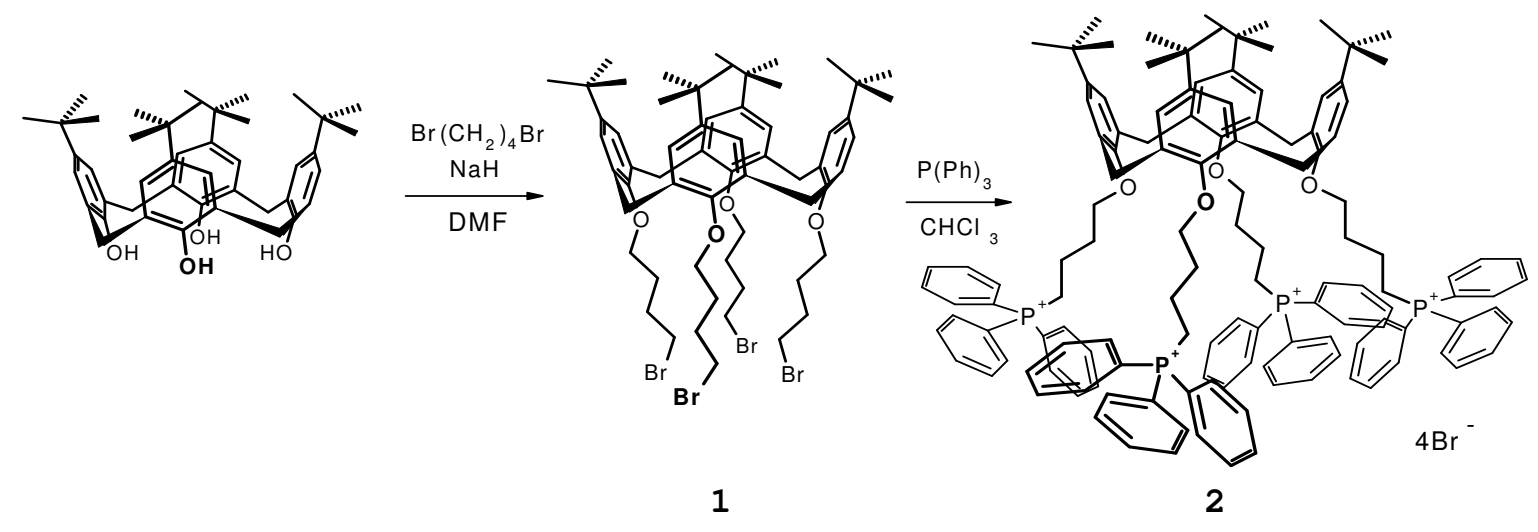

Scheme 1

URL: http:/mc.manuscriptcentral.com/tandf/gsch Email: suprachem@mail.cm.utexas.edu 
Scheme 2

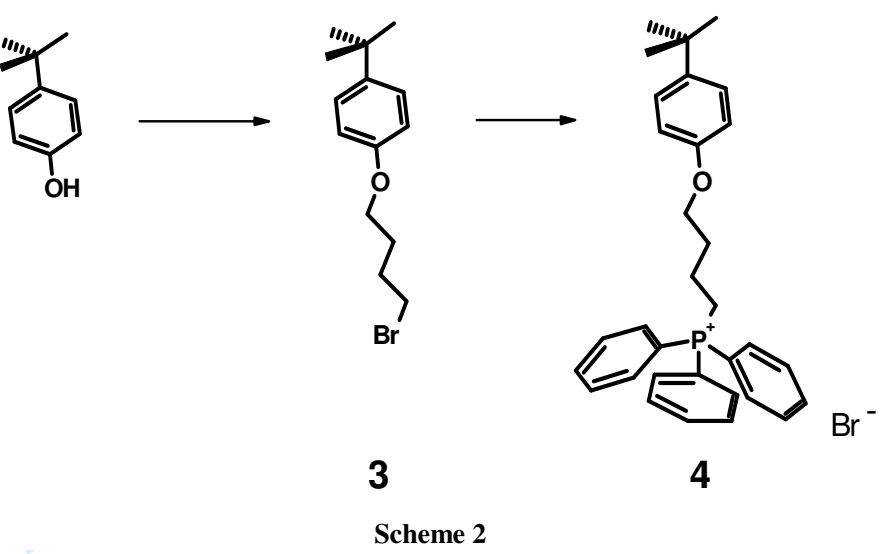


Fig. 1

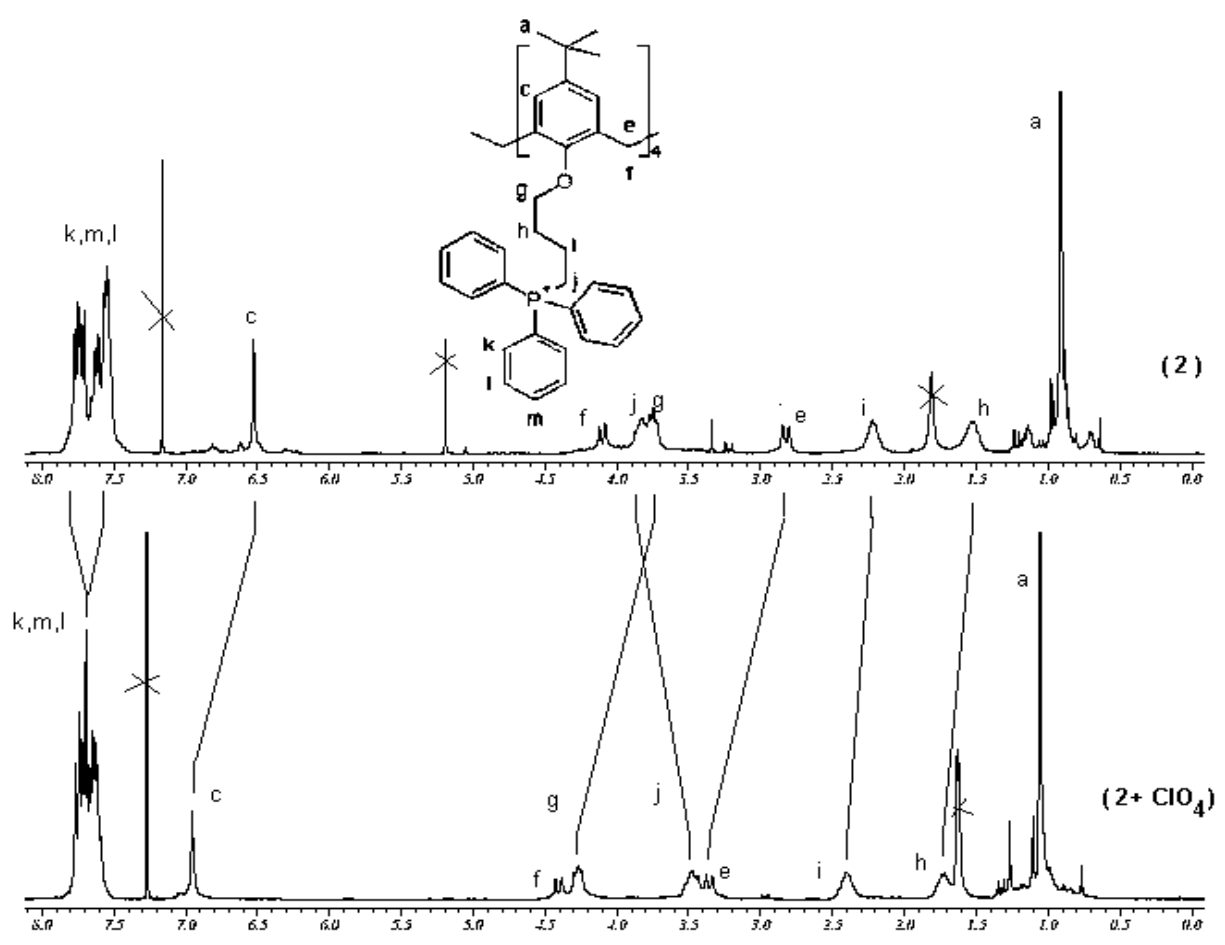

Fig. 1 Changes in ${ }^{1} \mathrm{H}$ NMR spectra of 2 in presence of $\mathrm{ClO}_{4}{ }^{-}$anion . 
Fig.2

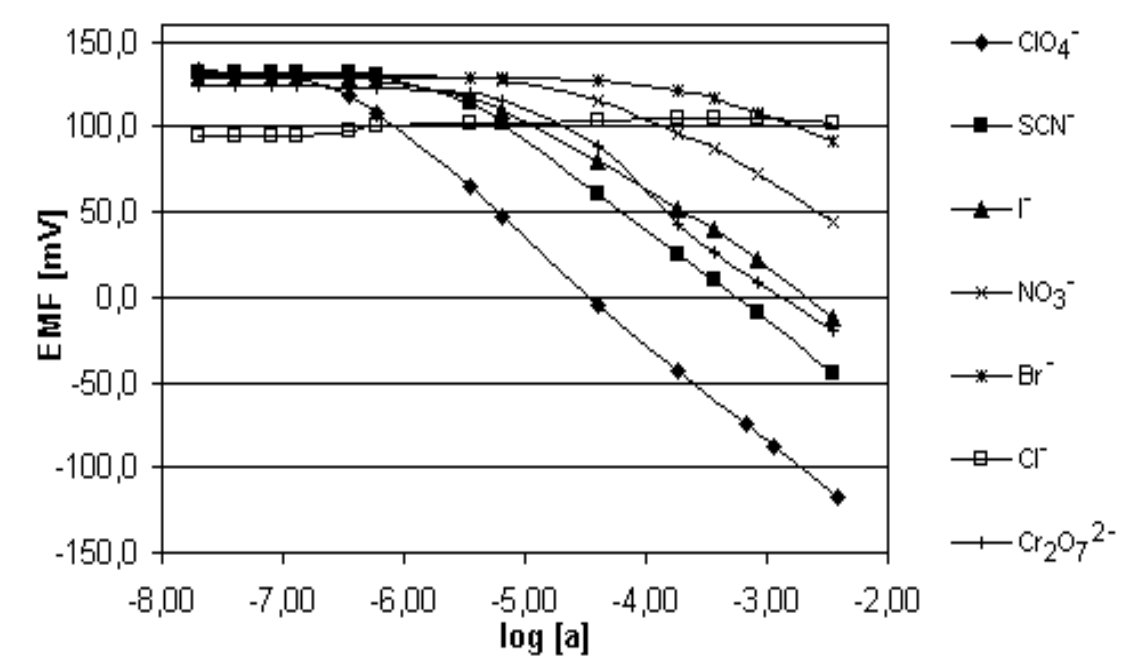

Fig.2 Potentiometric responses of electrode with ligand 2 to anions in MES/NaOH buffer $(\mathrm{pH}=5.5)$ and ionic strength adjusted with $10 \mathrm{mM} \mathrm{NaCl}$ solution. 


\title{
A New Phosphonium Calix[4]arene for Selective Anion
}

\section{Recognition: Synthesis and Studies in Solution and in Ion Selective Electrodes}

\author{
Radoslaw Pomecko, ${ }^{a, b}$ Zouhair Asfari, ${ }^{a}$ Véronique Hubscher-Bruder, ${ }^{a}$ \\ Maria Bochenska, ${ }^{b, c}$ and Françoise Arnaud-Neu, ${ }^{a, c}$ \\ ${ }^{\mathrm{a} D e p a r t m e n t ~ o f ~ A n a l y t i c a l ~ S c i e n c e s, ~ I P H C, ~ U M R ~} 7178$ (CNRS-ULP), \\ Ecole Européenne de Chimie, Polymères, Matériaux (ECPM), \\ 25 rue Becquerel, 67087 Strasbourg Cedex 2, France \\ ${ }^{\mathrm{b}}$ Department of Chemical Technology, Chemical Faculty, \\ Gdansk University of Technology, ul. Narutowicza 11/12, 80-264 Gdansk, Poland; \\ ${ }^{\mathrm{c}}$ Authors to whom correspondence should be addressed \\ (e-mail: farnaud@ chimie.u-strasbg.fr; marboch@altis.chem.pg.gda.pl)
}

\begin{abstract}
The synthesis and characterisation of a new tetra (triphenylphosphonium) p-tertbutylcalix[4]arene 2 is presented. Its interactions with anions were studied by ${ }^{1} \mathrm{H}$ and ${ }^{31} \mathrm{P}$ NMR and UV absorption spectrophotometry, showing the biggest interaction with $\mathrm{ClO}_{4}^{-}, \mathrm{I}^{-}$and $\mathrm{SCN}^{-}$. Anion selectivity in ion-selective PVC-membrane electrodes (ISEs) plasticized with o-NPOE containing ionophore 2 was also investigated. Compound 2 shows a potentiometric response for various anions with
\end{abstract}


the following selectivity pattern: $\mathrm{ClO}_{4}^{-}>\mathrm{SCN}^{-}>\mathrm{I}^{-}>\mathrm{Cr}_{2} \mathrm{O}_{7}^{2-}>\mathrm{NO}_{3}^{-}>\mathrm{Br}^{-}>$ $\mathrm{Cl}^{-}$.

Key Words: calix[4]arene, perchlorate, phosphonium group, anion complexation, ISE

\section{INTRODUCTION}

Anions play an important role in biological processes, e.g. in enzymatic reactions or in DNA coding. ${ }^{1}$ Perturbation of the anionic equilibria in organisms may be the origin of diseases. The increase of anion concentrations in ecosystems leads to environmental problems such as eutrophication due to an excess of phosphates and nitrates or the presence of long-lived radioelements such as iodine, technetium, and selenium in their anionic forms produced by the nuclear industry. ${ }^{2}$ Anions are relatively large and have also a wide variety of geometries which are important factors to be considered in the design of selective anion receptors. Therefore the recognition of anions is a topical challenge.

Design of sensors for monitoring the activity of chemical and biochemical species is an important issue in supramolecular chemistry. ${ }^{3,4}$ A large number of ionophores for potentiometric sensing of cations have been developed but the number of suitable sensors for anions is still rather limited. ${ }^{5}$ Anion binding can be achieved by neutral receptors (such as urea containing ligands) mainly through hydrogen bonding $^{5,6}$ or by positively charged ligands (for instance guanidinium or polyamine containing macrocycles) through electrostatic interaction. ${ }^{5,7,8}$ Calixarenes were used as molecular scaffold on which to graft such functional groups. ${ }^{9}$ For instance, the synthesis of amide, ${ }^{10-12}$ urea $^{13,14}$ or alkylammonium ${ }^{15}$ and pyridynium ${ }^{16}$ calixarene derivatives selective for anions were reported. ${ }^{17-19}$ The majority of the anion- 
selective electrodes described so far is based on lipophilic quarternary ammonium salts behaving as anion-exchangers or on metalloporphyrins, in which the kind of metal determines the selectivity for particular anions. ${ }^{20-22}$ Not many ligands containing phosphorus atoms were studied so far. Two such macrocycles applied in chemical sensors showed selective response for $\mathrm{ClO}_{4}{ }^{-}$anion, with, however little discrimination of $\mathrm{I}^{-}$and $\mathrm{SCN}^{-23,24}$ Recently a di (triphenylphosphonium) calix[4]arene has been synthesised which exhibited also some anion recognition properties. ${ }^{25,26}$ By attaching four phosphonium moieties to a calix[4]arene scaffold, it was expected to enhance the selectivity for tetrahedral or spherical anions, taking advantage of the preorganization of the ligand.

We report here the synthesis and characterisation of the tetra (triphenylphosphonium) p-tert-butylcalix[4]arene ligand 2 as well as its binding properties in solution towards a large variety of anions of different size, charge and geometry. Its behaviour in PVC-membrane electrodes is also presented. The monomeric subunit 4 was synthesised for comparison purpose. Our results are compared to those of known anion selectives electrodes.

\section{EXPERIMENTAL}

\section{Materials and Methods}

${ }^{1} \mathrm{H}$ and ${ }^{31} \mathrm{P}$ NMR spectra were recorded in $\mathrm{CDCl}_{3}$ and $\mathrm{CD}_{3} \mathrm{CN}$ on a Brucker $\mathrm{SY} 300$ $\mathrm{MHz}$ and a SY400 MHz, respectively. FAB mass spectra were obtained on a VG analytical ZAB HF instrument. All reagents and solvents were commercial and used without further purification, except THF which was dried and freshly distilled before 
used for preparation of ion selective membranes. PVC (high molecular weight poly(vinyl chloride), 2-nitrophenyl octyl ether (NPOE), bis-ethylhexylsebacate (BEHS), (2-morpholino)ethanesulfonic acid monohydrate (MES), were from Fluka selectophore. The $\mathrm{LiClO}_{4}, \mathrm{CsClO}_{4}$ and sodium salts: $\mathrm{Cl}^{-}, \mathrm{Br}^{-}, \mathrm{I}^{-}, \mathrm{ClO}_{4}^{-}, \mathrm{SCN}^{-}, \mathrm{NO}_{3}^{-}$, $\mathrm{SO}_{4}{ }^{2-}, \mathrm{CO}_{3}{ }^{2-}, \mathrm{HPO}_{4}{ }^{2-}, \mathrm{PO}_{4}{ }^{3-}, \mathrm{Cr}_{2} \mathrm{O}_{7}{ }^{2-}$, citrate, acetate, benzoate, and oxalate were of p.a. grade. All aqueous salt solutions were prepared with demineralised water (conductivity $<1.0 \mu \mathrm{S} / \mathrm{cm}$ ).

\section{Synthesis}

\section{Scheme 1}

Tetrakis-(4-triphenylphosphonium-butoxy)-tetrakis-p-tert-butylcalix[4]arene

tetrabromide 2. Tetrakis-(4-bromobutoxy)-tetrakis-p-tert-butylcalix[4]arene 1 (1.184 g, $1.00 \mathrm{mmol})$ was dissolved in chloroform $(30 \mathrm{ml})$. After a few minutes of stirring triphenylphosphine $(5.248 \mathrm{~g}, 20.00 \mathrm{mmol})$ and chloroform $(20 \mathrm{ml})$ were added. After 6 days of refluxing the mixture was cooled and solvent was evaporated. The residue was dissolved in dichloromethane. The excess of triphenylphosphine was precipitated from methanol and filtered. The organic layer was evaporated and the crude product was dissolved in dichloromethane. Chromatography on a silica column with 90:10 dichloromethane: methanol mixture as eluent gave tetrakis-(4triphenylphosphonium-butoxy)-tetrakis-p-tert-butylcalix[4] arene tetrabromide $(0.67$ g, 30\%). $\mathrm{C}_{132} \mathrm{H}_{144} \mathrm{O}_{4} \mathrm{P}_{4} \mathrm{Br}_{4} \quad \mathrm{M}=2238.10 \mathrm{~g} / \mathrm{mole} \delta_{\mathrm{H}}\left(300 \mathrm{MHz} ; \mathrm{CDCl}_{3} ; \mathrm{Me}_{4} \mathrm{Si}\right) 7.88-$ $7.76(24 \mathrm{H}, \mathrm{m}, \mathrm{P}-\mathrm{Ar}-H), 7.71-7.59(36 \mathrm{H}, \mathrm{m}, \mathrm{P}-\mathrm{Ar}-H), 6.63(8 \mathrm{H}, \mathrm{s}, \mathrm{Ar}-H), 4.23(4 \mathrm{H}$, d, $\left.J=13.0 \mathrm{~Hz}, \mathrm{Ar}-\mathrm{CH}_{2}-\mathrm{Ar}\right), 4.01-3.78\left(16 \mathrm{H}, \mathrm{m},-\mathrm{CH}_{2}-\mathrm{P}\right.$ and $\left.\mathrm{Ar}-\mathrm{O}-\mathrm{CH}_{2}\right), 2.91(4 \mathrm{H}$, $\left.\mathrm{d}, J=13.0 \mathrm{~Hz}, \mathrm{Ar}-\mathrm{CH}_{2}-\mathrm{Ar}\right), 2.41-2.24\left(8 \mathrm{H}, \mathrm{m},-\mathrm{CH}_{2^{-}}\right), 1.72-1.56\left(8 \mathrm{H}, \mathrm{m},-\mathrm{CH}_{2^{-}}\right)$, $1.02\left(36 \mathrm{H}, \mathrm{s},-\mathrm{C}\left(\mathrm{CH}_{3}\right)_{3}\right) . \mathrm{m} / \mathrm{z}(\mathrm{FAB}(+)) 479.5\left(\mathrm{M}^{4+}, 100 \%\right)$. 


\section{Tetrakis-(4-triphenylphosphonium-butoxy)-tetrakis-p-tert-butylcalix[4]arene}

tetrahexafluorophosphate 2a. Tetrakis-(4-triphenylphosphonium-butoxy)-tetrakis-ptert-butylcalix[4]arene tetrabromide $(0.100 \mathrm{~g}, 0.045 \mathrm{mmoles})$ was dissolved in acetonitrile $(1 \mathrm{ml})$. Then $0.062 \mathrm{~g}(0.245 \mathrm{mmol})$ of $\mathrm{AgPF}_{6}$ was dissolved in acetonitrile and added dropwise to the ligand solution. After $24 \mathrm{~h}$ the precipitate of $\mathrm{NaBr}$ was removed and the solution was evaporated. $0.090 \mathrm{~g}(0.036$ mmole $)$ of tetrakis-(4-triphenylphosphonium-butoxy)-tetrakis-p-tert-butylcalix[4]arene tetrahexafluorophosphate was obtained. $\mathrm{C}_{132} \mathrm{H}_{144} \mathrm{O}_{4} \mathrm{P}_{4}\left(\mathrm{PF}_{6}\right)_{4} \quad \mathrm{M}=2498.31 \mathrm{~g} / \mathrm{mole} \delta_{\mathrm{H}}$ (500 MHz; $\left.\mathrm{CDCl}_{3} ; \mathrm{Me}_{4} \mathrm{Si}\right)$ 7.80-7.66 (60H, m, P-Ar-H), 7.04 (8H, s, Ar- H), 4.47 $\left(4 \mathrm{H}, \mathrm{d}, J=13.0 \mathrm{~Hz}, \mathrm{Ar}-\mathrm{CH}_{2}-\mathrm{Ar}\right), 4.24-4.15\left(8 \mathrm{H}, \mathrm{m}, \mathrm{Ar}-\mathrm{O}-\mathrm{CH}_{2}\right), 3.47(4 \mathrm{H}, \mathrm{d}, J=$ 13.0 Hz, Ar- $\left.\mathrm{CH}_{2}-\mathrm{Ar}\right), 3.38-3.25\left(8 \mathrm{H}, \mathrm{m},-\mathrm{CH}_{2}-\mathrm{P}\right), 2.49-2.38\left(8 \mathrm{H}, \mathrm{m},-\mathrm{CH}_{2}-\right), 1.81-$ $1.65\left(8 \mathrm{H}, \mathrm{m},-\mathrm{CH}_{2^{-}}\right), 1.12\left(36 \mathrm{H}, \mathrm{s},-\mathrm{C}\left(\mathrm{CH}_{3}\right)_{3}\right)$.

Tetrakis-(4-bromobutoxy)-tetrakis-p-tert-butylcalix[4]arene 1. The suspension of $p$ tert-butylcalix[4]arene $(1.947 \mathrm{~g}, 3.00 \mathrm{mmol})$ and $\mathrm{NaH}$ in oil washed three times with hexane $(0.700 \mathrm{~g}, 29.17 \mathrm{mmol})$ were stirred at room temperature in DMF (50 ml) for 1h. Then 1,4-dibromobutane $(12.947 \mathrm{~g}, 59.06 \mathrm{mmol})$ was added and the mixture was heated to $80{ }^{\circ} \mathrm{C}$. After 4 days of heating, the mixture was cooled and $\mathrm{MeOH}(20 \mathrm{ml})$ was added. After removing of the solvent, the residue was dissolved in dichloromethane and water and acidified with $1 \mathrm{M} \mathrm{HCl}$. The organic layer was dried over $\mathrm{Na}_{2} \mathrm{SO}_{4}$, filtered and evaporated. After precipitation from methanol pure tetra(4-bromobutoxy)-tetrakis-p-tert-butylcalix[4]arene (1.52 g, 43\%) was obtained. $\mathrm{C}_{60} \mathrm{H}_{84} \mathrm{O}_{4} \mathrm{Br}_{4} \quad \mathrm{M}=1188.94 \mathrm{~g} / \mathrm{mole} \delta_{\mathrm{H}}\left(300 \mathrm{MHz}, \mathrm{CDCl}_{3}\right) 6.79(8 \mathrm{H}, \mathrm{s}, \mathrm{Ar}-H), 4.36$ 
$\left(4 \mathrm{H}, \mathrm{d}, J=13.0 \mathrm{~Hz}, \mathrm{Ar}-\mathrm{CH}_{2}-\mathrm{Ar}\right), 3.91\left(8 \mathrm{H}, \mathrm{t}, J=6.9 \mathrm{~Hz},-\mathrm{CH}_{2}-\mathrm{O}-\right), 3.53(8 \mathrm{H}, \mathrm{t}, J=$ $\left.6.9 \mathrm{~Hz},-\mathrm{CH}_{2}-\mathrm{Br}\right), 3.15\left(4 \mathrm{H}, \mathrm{d}, J=13.0 \mathrm{~Hz}, \mathrm{Ar}-\mathrm{CH}_{2}-\mathrm{Ar}\right), 2.23-2.16\left(8 \mathrm{H}, \mathrm{m},-\mathrm{CH}_{2}-\right)$, 2.09-1.98 (8H, m, - $\left.\mathrm{CH}_{2^{-}}\right), 1.09\left(36 \mathrm{H}, \mathrm{s},-\mathrm{C}\left(\mathrm{CH}_{3}\right)_{3}\right)$.

\section{Scheme 2}

4-Bromobutoxy-p-tert-butyl-phenol $\mathbf{3}$ and triphenylphosphonium-butoxy-p-tert-butylphenol bromide 4.

Compounds $\mathbf{3}$ and $\mathbf{4}$ were synthesised according to the procedures which were used for the preparation of 1 and 2. Compound 3: $(60 \%) . \mathrm{C}_{14} \mathrm{H}_{21} \mathrm{OBr} \quad \mathrm{M}=285.22 \mathrm{~g} / \mathrm{mole} \delta_{\mathrm{H}}(300$ $\left.\mathrm{MHz}, \mathrm{CDCl}_{3}\right) 7.32(2 \mathrm{H}, \mathrm{d}, J=9.0 \mathrm{~Hz}, \mathrm{Ar}-H), 6.86(2 \mathrm{H}, \mathrm{d}, J=9.0 \mathrm{~Hz}, \operatorname{Ar}-H), 3.99(2 \mathrm{H}$, $\left.\mathrm{t}, J=5.8, \mathrm{Ar}-\mathrm{O}-\mathrm{CH}_{2}\right), 3.51\left(2 \mathrm{H}, \mathrm{t}, J=6.6, \mathrm{CH}_{2}-\mathrm{Br}\right), 2.14-2.03\left(2 \mathrm{H}, \mathrm{m},-\mathrm{CH}_{2}-\right), 2.00-$ $1.90\left(2 \mathrm{H}, \mathrm{m},-\mathrm{CH}_{2^{-}}\right), 1.33\left(9 \mathrm{H}, \mathrm{s},-\mathrm{C}\left(\mathrm{CH}_{3}\right)_{3}\right)$.

Compound 4: (40\%). $\mathrm{C}_{32} \mathrm{H}_{36} \mathrm{OPBr} \quad \mathrm{M}=547.52 \mathrm{~g} / \mathrm{mole} \delta_{\mathrm{H}}\left(300 \mathrm{MHz}, \mathrm{CDCl}_{3}\right)$ 7.86-7.72 $(9 \mathrm{H}, \mathrm{m}, \mathrm{P}-\mathrm{Ar}-H), 7.69-7.58(6 \mathrm{H}, \mathrm{m}, \mathrm{P}-\mathrm{Ar}-H), 7.23(2 \mathrm{H}, \mathrm{d}, J=8.8 \mathrm{~Hz}, \mathrm{Ar}-H), 6.72(2 \mathrm{H}$, $\mathrm{d}, J=8.8 \mathrm{~Hz}, \mathrm{H}-\mathrm{Ar}), 4.01\left(2 \mathrm{H}, \mathrm{t}, J=5.8, \mathrm{Ar}-\mathrm{O}-\mathrm{CH}_{2}\right), 3.93-3.80\left(2 \mathrm{H}, \mathrm{m},-\mathrm{CH}_{2}-\mathrm{P}\right), 2.21-$ $2.12\left(2 \mathrm{H}, \mathrm{m},-\mathrm{CH}_{2^{-}}\right), 1.92-1.81\left(2 \mathrm{H}, \mathrm{m},-\mathrm{CH}_{2^{-}}\right), 1.25\left(9 \mathrm{H}, \mathrm{s},-\mathrm{C}\left(\mathrm{CH}_{3}\right)_{3}\right)$.

\section{NMR studies of anion-ligand interaction}

The NMR experiments were carried in $\mathrm{CDCl}_{3}$ and in $\mathrm{CD}_{3} \mathrm{CN}$ solutions. The solution of ligand in $\mathrm{CDCl}_{3}$ was left for $24 \mathrm{~h}$ in contact with an excess of 6 equivalents of the solid sodium salts ( $\mathrm{I}^{-}, \mathrm{NO}_{3}{ }^{-}, \mathrm{SCN}^{-}, \mathrm{ClO}_{4}{ }^{-}, \mathrm{SO}_{4}{ }^{2-}, \mathrm{S}_{2} \mathrm{O}_{3}{ }^{2-}, \mathrm{CrO}_{4}{ }^{2-}, \mathrm{MoO}_{4}{ }^{2-}, \mathrm{Cr}_{2} \mathrm{O}_{7}{ }^{2-}$ ) until equilibration and then the spectra were recorded. Different alkali metal $\left(\mathrm{Li}^{+}, \mathrm{Na}^{+}, \mathrm{Cs}^{+}\right)$ and tetraethylammonium perchlorates were dissolved in a solution of ligand in $\mathrm{CD}_{3} \mathrm{CN}$, the other experimental conditions remaining the same. 


\section{Stability constant determination}

The procedures and experimental conditions were the same in both solvents methanol and acetonitrile, except the nature of the background electrolyte used to maintain the ionic strength constant at $0.01 \mathrm{M}$, which was $\mathrm{NaBr}$ in methanol and $\mathrm{Et}_{4} \mathrm{NBr}$ in acetonitrile. Small volumes $(0.05 \mathrm{ml})$ of the salt solution $\left(2.5 \times 10^{-3} \mathrm{M}\right)$ were added to $2 \mathrm{ml}$ of the ligand solution $\left(10^{-4} \mathrm{M}\right)$ directly into the spectrophotometric cell thermoregulated at $25^{\circ} \mathrm{C}$. For each volume added, the spectrum of the solution was recorded on a Cary 3 spectrophotometer (Varian) between 250 and $300 \mathrm{~nm} .17$ additions was enough to complete the titration. At least three independent experiments have been performed. The interpretation of the spectra using the program Specfit ${ }^{27}$ led to the determination of the concentration ratio $\beta_{\mathrm{x} 1}=\left[\mathrm{A}_{\mathrm{x}} \mathrm{L}^{4-\mathrm{xn}}\right] /\left(\left[\mathrm{A}^{\mathrm{n}-}\right]^{\mathrm{x}}\left[\mathrm{L}^{4+}\right]\right)\left(\right.$ where $\mathrm{A}^{\mathrm{n}-}$ is the anion and $\mathrm{L}^{4+}$ the ligand).

\section{Ion selective membrane electrodes (ISE)}

The membranes were prepared by dissolving $4 \mathrm{mg}$ of the ionophore 2 or $4,60 \mathrm{mg}$ of PVC, $120 \mathrm{mg}$ of plasticizer (o-NPOE), about $184 \mathrm{mg}$ in total, in $1.5 \mathrm{~mL}$ of dried and distilled THF. Each solution was poured into a glass ring ( $24 \mathrm{~mm}$ in diameter). After slow evaporation of the solvent overnight, several membranes of $7 \mathrm{~mm}$ diameter were cut from each mother membrane and incorporated into $\mathrm{Ag} / \mathrm{AgCl}$ Philips electrodes bodies of IS 561 type (Moeller S.A., Zurich). Three identical electrodes were always studied. ${ }^{28}$ The EMF measurements were carried out at $20^{\circ} \mathrm{C}$ using Lawson Lab 16 EMF, multi-channel voltmeter or in some cases using Metrohm 654 voltmeter. A double-junction reference Radelkis 0P0820P electrode with 1M 
$\mathrm{CH}_{3} \mathrm{COOLi}$ solution in the bridge cell was used. The measurements were carried out using the cells of the type:

$\mathrm{Ag}|\mathrm{AgCl}| 1 \mathrm{M} \mathrm{KCl} \mid 1 \mathrm{M} \mathrm{CH} \mathrm{CHOLi}_{3}$ | sample || membrane || $0.05 \mathrm{M} \mathrm{MES/NaOH}$, $0.01 \mathrm{M} \mathrm{NaCl}|\mathrm{AgCl}| \mathrm{Ag}$.

The calibration curves were obtained by addition of standard solutions of different anions to $50 \mathrm{ml}$ of $0.01 \mathrm{M} \mathrm{NaCl}$ in $0.05 \mathrm{M} \mathrm{MES} / \mathrm{NaOH}$ buffer solution of $\mathrm{pH}=5.5$. They were also measured by successive dilution of initial $5 \times 10^{-2} \mathrm{M}$ salt solutions until further dilution resulted in no potential change. The $\mathrm{NaCl}$ was applied as the supporting electrolyte based on preeliminary experiment in which studied membrane electrode showed no response for changing of $\mathrm{Cl}^{-}$anion concentration. Potentiometric sensitivity to $\mathrm{ClO}_{4}{ }^{-}$anions was studied also by calibration of the membrane electrodes (PVC/o-NPOE/2) in pure $\mathrm{NaClO}_{4}$ water solution. Potentiometric selectivity coefficients $\left(\log K^{\text {pot }}{ }_{\mathrm{ClO}, J}\right)$ were determined by the Separate Solution Method (SSM) ${ }^{29}$ and were calculated (equation 1), by using the EMF values for the measured ion activities $\mathrm{a}_{\mathrm{I}}$ at the concentration $10^{-2} \mathrm{M}$ :

$$
\log K_{I, J}^{p o t}=\frac{\left(E_{J}-E_{I}\right) z_{I} F}{2.303 R T}+\left(1-\frac{z_{I}}{z_{J}}\right) \log a_{I}
$$

In equation (1), $I$ and $J$ correspond to the primary and the interfering anions, respectively and $z_{I}, z_{J}$ corespond to their charges. The values of $\log K^{\text {pot }}{ }_{\mathrm{ClO}, J}$ were derived from measurements performed with perchorate as primary anion, i.e. the best complexed anion, $J$ referring to the other studied anions. 
Potentiometric selectivity coefficients $\left(\log K_{I, \mathrm{Cl}}^{\text {pot }}\right)$ were also determined by the Fix Interference Method (FIM). ${ }^{29}$ The concentration of $\mathrm{NaCl}$ in each measured anion solution was $10 \mathrm{mM}$. Values of $\log K_{I, \mathrm{Cl}}^{\text {pot }}$ were determined using chloride as interfering anion and in this case, $I$ corresponds to the other anions.

\section{RESULTS AND DISCUSSION}

The tetra (triphenylphosphonium) p-tert-butylcalix[4]arene 2 has been obtained in $30 \%$ yield by refluxing in chloroform the tetrabromobutoxycalix[4]arene 1 in presence of 20 equivalents of triphenylphosphine during 6 days as represented in Scheme 1. The tetrabromocalix[4]arene 1 was prepared by reacting the p-tertbutylcalix[4]arene in DMF at $80^{\circ} \mathrm{C}$ during 4 days with 1 ,4-dibromobutane in the presence of sodium hydride. This compound adopts the cone conformation as shown by the presence in its ${ }^{1} \mathrm{H}$ NMR spectrum of an $\mathrm{AB}$ system at 4.36 and $3.15 \mathrm{ppm}$. The monomeric unit 4 was obtained according to the same procedure in $40 \%$ yield (Scheme 2)

\section{Figure 1}

The affinity of ligand 2 for a series of anions of different charge, size and geometry: $\mathrm{I}^{-}, \mathrm{NO}_{3}{ }^{-}, \mathrm{SCN}^{-}, \mathrm{ClO}_{4}{ }^{-}, \mathrm{SO}_{4}{ }^{2-}, \mathrm{S}_{2} \mathrm{O}_{3}{ }^{2-}, \mathrm{CrO}_{4}{ }^{2-}, \mathrm{MoO}_{4}{ }^{2-}, \mathrm{Cr}_{2} \mathrm{O}_{7}{ }^{2-}$ has been studied using two approaches. A first assessment of the ligand interaction with anions was obtained using ${ }^{1} \mathrm{H}$ and ${ }^{31} \mathrm{P}$ NMR spectroscopy coupled with solid/liquid extraction. Among the anions tested only $\mathrm{ClO}_{4}^{-}, \mathrm{I}^{-}$and $\mathrm{SCN}^{-}$led to modifications of the signals of the ligand in $\mathrm{CDCl}_{3}$ after equilibration with an excess of 6 equivalents of the solid sodium salts (Table 1). These three anions are all of different geometry, 
and they are lipophilic. ${ }^{30}$ They might exchange with bromide anions of the ligand because of their higher lipophilicity.

Fig. 1 shows the ${ }^{1} \mathrm{H}$ NMR spectra of 2 alone and in presence of $\mathrm{NaClO}_{4}$. The important changes (expressed as $\Delta(\delta)$ ) were observed for the $\mathrm{CH}_{2}$ protons adjacent to the phenolic oxygen atoms ( $\mathrm{g}$ atoms) and for the $\mathrm{CH}_{2}$ protons adjacent to the phosphorus atoms (j atoms). They correspond to a multiplet from 4.01 to $3.78 \mathrm{ppm}$ which undergoes shifts and gives two multiplets from 4.32 to $4.23 \mathrm{ppm}$ for the $\mathrm{g}$ atoms and from 3.56 to 3.42 for the $\mathrm{j}$ atoms. The signals corresponding to the $\mathrm{AB}$ system (f,e atoms) at 4.23 and $2.91 \mathrm{ppm}$ in 2 are also shifted to give another $A B$ system at 4.40 and $3.35 \mathrm{ppm}$ in the presence of perchlorate anion. An important shift of the signal corresponding to the aromatic protons (c atoms) is also observed (Table 1). These changes clearly indicate strongest interaction of ligand with perchlorate, which is further confirmed by ${ }^{31} \mathrm{P}$ NMR. The signal of the phosphorus atoms at $25.74 \mathrm{ppm}$ in the free ligand is shifted to $24.76 \mathrm{ppm}$ in the presence of perchlorate ions. In the case of iodide and thiocyanate, the signal of the phosphorus atoms is shifted to 25.55 and 24.99 ppm, respectively. These changes, in agreement with the ${ }^{1} \mathrm{H}$ NMR spectra, suggest significant interactions between these anions and the ligand. It is important to note that no change was observed in the ${ }^{1} \mathrm{H}$ NMR spectra of the phosphonium monomer 4 in the presence of all these anions introduced as sodium or lithium salts.

The ${ }^{1} \mathrm{H}$ NMR experiments were repeated in deutered acetonitrile with perchlorate salts of different alkali metals and tetraethylammonium cation. The spectra of the ligand are very similar in both solvents. The presence of $\mathrm{NaClO}_{4}$ induces shifts of 
the same signals as in $\mathrm{CDCl}_{3}$. With $\mathrm{LiClO}_{4}$, the signal of methylene protons adjacent to the phenolic oxygen atoms (protons g) shifts from 3.74 to $4.36 \mathrm{ppm}$. This shift is larger than that observed in the presence of $\mathrm{NaClO}_{4}$. With both salts the shifts corresponding to the signals of the $\mathrm{j}$ protons next to the $\mathrm{P}$ atoms (which are supposed to interact with perchlorate) are similar. With $\mathrm{CsClO}_{4}$, the only shift observed is that for the $\mathrm{j}$ protons, but the value is very small in comparison to the effect of the other salts (-0.06 ppm with $\mathrm{CsClO}_{4},-0.52$ with $\mathrm{LiClO}_{4}$ and -0.53 with $\mathrm{NaClO}_{4}$ ). In the case of $\mathrm{Et}_{4} \mathrm{NClO}_{4}$ the shift of the $\mathrm{j}$ protons was much stronger than in case of $\mathrm{Cs}^{+}$but twice smaller than for $\mathrm{Li}^{+}$or $\mathrm{Na}^{+}$salts. The changes observed suggest that ligand/anion interaction is connected with the nature of the counter ion and its affinity to the ligand. A similar ${ }^{1} \mathrm{H}$ NMR experiment has been performed in acetonitrile with $\mathrm{NaClO}_{4}$ and $2 \mathrm{a}$, equivalent to 2 in which the bromide ions have been replaced by $\mathrm{PF}_{6}^{-}$anions. The results presented in table 2 show similar changes as in the case of $2+\mathrm{NaClO}_{4}$. With this lipophilic anion, for which no exchange is normally possible, there is still a significant shift of the $\mathrm{j}$ protons close to the phosphorus atoms in presence of $\mathrm{ClO}_{4}{ }^{-}$, suggesting complexation of this anion.

The ligand-anion interaction has also been followed by UV absorption spectrophotometry in methanol and acetonitrile. No changes were observed in the spectrum of the ligand upon addition of the anions (introduced as their sodium salts) in methanol. However, in acetonitrile, significant modifications of the spectra appeared in the presence of perchlorate, thiocyanate and iodide anions, i.e. the same anions for which shifts were noticed in NMR spectroscopy. These changes were interpreted using program Specfit ${ }^{27}$ by the formation of 1:1 (anion:ligand) complexes with sodium perchlorate $\left(\log \beta_{11}=3.81 \pm 0.02\right)$ and with lithium perchlorate $\left(\log \beta_{11}\right.$ 
$=3.71 \pm 0.04)$. Changes in presence of sodium thiocyanate were interpreted by the formation of 2:1 complex $\left(\log \beta_{21}=8.7 \pm 0.3\right)$. The different structures of the two anions (tetrahedral for perchlorate and linear for thiocyanate) may account for the difference in the stoichiometries of the complexes. The strong absorption of iodide precluded any interpretation of the spectra. In case of the other anions studied in this solvent, the very small spectral variations observed suggest only weak anion interactions with ligand 2.

Ligand 2 was applied as new sensing material in ion-selective PVC membrane electrodes (ISEs). The potentiometric response towards the same anions, including also chloride, bromide, phosphate, hydrogenophosphate, carbonate, acetate, oxalate, citrate and benzoate anions was studied using two different plasticizers: BEHS and o-NPOE in the electrode membranes. Only the membranes containing o-NPOE were stable and long lasting, so only this plasticizer was chosen for further studies. Several PVC/o-NPOE membranes were prepared but the membrane without any additives (anionic ${ }^{21,31,32}$ or cationic ${ }^{17,33}$ sites) was the best choice. The composition of the membrane was the following: PVC/o-NPOE (1/2) containing $2 \%$ wt of ionophore 2 or 4 . Electrodes were calibrated using buffer solution (2morpholino)ethanesulfonic acid monohydrate $(\mathrm{MES})-\mathrm{NaOH}(\mathrm{pH}=5.5)$ containing sodium salts of anions. The ionic strength was adjusted with $10 \mathrm{mM} \mathrm{NaCl}$. Sensing properties of the membrane electrode are presented in Fig. 2. and are summarised in Table 3 .

The electrodes showed Nernstian response and highest selectivity for $\mathrm{ClO}_{4}{ }^{-}$ions in buffered solution $(\mathrm{pH}=5.5)$ and in water $(\mathrm{pH}=6.5)$. They also showed close to 
Nernstian response to $\mathrm{I}^{-}, \mathrm{NO}_{3}{ }^{-}, \mathrm{SCN}^{-}$. There was no significant reaction for $\mathrm{SO}_{4}{ }^{2-}$, $\mathrm{CO}_{3}{ }^{2-}, \mathrm{HPO}_{4}{ }^{2-}, \mathrm{PO}_{4}{ }^{3-}$, citrate, acetate, benzoate and oxalate. Rather quick (within $15-$ $20 \mathrm{~s}$ ) and stable response of the electrodes was observed during the measurements and the answer was fully reversible. The lifetime of electrode with ionophore 2 is more than three weeks. Selectivity coefficients $K^{\text {pot }}{ }_{\mathrm{ClO}, J}$ measured by the separate solution method $(\mathrm{SSM})^{29}$ in $10 \mathrm{mM}$ buffered $(\mathrm{pH}=5.5)$ or $100 \mathrm{mM}$ unbuffered $(\mathrm{pH}=6.5)$ solutions of the corresponding sodium salts are given in Table 4. Ligand 2 provides the following selectivity order: $\mathrm{ClO}_{4}{ }^{-}>\mathrm{SCN}^{-}>\mathrm{I}^{-}>\mathrm{Cr}_{2} \mathrm{O}_{7}{ }^{2-}>\mathrm{NO}_{3}^{-}>$ $\mathrm{Br}^{-}>\mathrm{Cl}^{-}$, which is quite similar to the Hofmeister series observed for the typical ion exchanger, tetradodecylammonium tetrakis(4-chlorophenyl)borate (TDMACl). ${ }^{3,18,34}$ The selectivity pattern of electrodes containing the phosphonium monomer 4 is similar. However the slope and linear range are not as good as the coresponding values for the electrodes with compound 2.

Figure 2

Table 5 allows the comparison between the performances of ligand 2 and several perchlorate selective ionophores when incorporated in ion selective electrodes. Ligand 2 displays better potentiometric properties than protonated cyclam or its copper complex and than phosphodithiamacrocycle PS2M. For instance the detection limit is $10^{-7}$ $\mathrm{mol} / \mathrm{dm}^{3}$ with ligand 2 instead of $4.2 \times 10^{-6} \mathrm{~mol} / \mathrm{dm}^{3}$ with cyclam. Ligand 2 presents generally higher selectivities than PS2M, TDMACl, cyclam and $[\mathrm{Cu}(\mathrm{cyclam})]^{2+}$. In particular the selectivities of 2 for $\mathrm{ClO}_{4}{ }^{-}$over halides are remarkable. The best performances of ligand $\mathbf{2}$ as compared to these ligands could be exploited despite its complicated synthesis. 


\section{CONCLUSION}

We have synthesised a new tetra(triphenylphosphonium) p-tert-butylcalix[4]arene in the cone conformation. As shown by ${ }^{1} \mathrm{H}$ and ${ }^{31} \mathrm{P}$ NMR and UV spectrophotometry, the compound proved to interact selectively with some anions, namely $\mathrm{ClO}_{4}{ }^{-}, \mathrm{SCN}^{-}$, and $\mathrm{I}^{-}$. This interaction appeared to be dependent on the nature of the alkali counter ion. This compound has also been incorporated in PVC-membrane electrodes as ionophore-sensing material for anions. The following selectivity order was found: $\mathrm{ClO}_{4}^{-}>\mathrm{SCN}_{6}^{-}>\mathrm{I}^{-}>\mathrm{Cr}_{2} \mathrm{O}_{7}^{2-}>\mathrm{NO}_{3}^{-}>\mathrm{Br}^{-}>\mathrm{Cl}^{-}$which is similar to the Hofmeister series observed for typical ion exchangers. However the performances of such electrodes are much better than the electrodes with the corresponding monomeric subunit. These results suggest that the interaction between the ligand and the anions may be a combination of electrostatic contribution and complementarity between the cavity formed by the phosphonium groups attached to the calixarene and the anion. Structural variations around this molecule, as for instance those concerning the nature of the substituents on the functional groups, are currently examined in order to optimise these selectivities.

\section{Acknowledgements}

R.P. gratefully acknowledges Gdansk University of Technology, Poland, and the Ministère de la Recherche et des Nouvelles Technologies, France (Cotutelles de thèses), for financial support. 


\section{References}

1. Beer, P.D.; Hayes, E. Coord. Chem. Rev. 2003, 240, 167.

2. Sessler, J.L.; Sansom, P.I.; Andrievsky, A.; Kral, V. in Supramolecular Chemistry of Anions, Bianchi, A., Bowman-James, K., Garcia-Espana, E., Eds.; John Wiley-VCH: New York, 1997; ch. 10, p. 355.

3. Bakker, E.; Buhlmann, P.; Pretsch, E. Chem. Rev. 1997, 97, 3124.

4. Buhlmann, P.; Pretsch, E.; Bakker, E. Chem. Rev. 1998, 98, 1593.

5. Beer, P.D.; Gale, P.A. Angew. Chem. Int. Ed. 2001, 40, 486.

6. Amemiya, S.; Buhlmann, P.; Umezawa, Y.; Jagessar, R.C.; Burns, D.H. Anal. Chem. 1999, 71, 1049.

7. Schmidtchen, F. P.; Berger, M. Chem. Rev. 1997, 97, 1609.

8. Beer, P.D.; Cadman, J. Coord. Chem. Rev. 2000, 205, 31.

See also Gale, P.A. Coord. Chem. Rev. 2001, 213, 79; Gale, P.A. Coord. Chem. Rev. 2003, 240, 191.

9. Matthews, S.E.; Beer, P.D. in Calixarenes 2001; Asfari, Z., Böhmer, V., Harrowfield, J., Vicens, J., Eds.; Kluwer Academic: Dordrecht, 2001; ch. 23, p. 421.

10. Falana, O.M.; Koch, H.F.; Roundhill, D.M.; Lumetta, G.J.; Hay, B.P. Chem. Commun. 1998, 503.

11. Cameron, B.R.; Loeb, S. Chem. Commun. 1997, 573.

12. Nam, K.C.; Chun, J.C.; Kang, S.O.; Ko, S.W. Bull. Korean Chem. Soc. 1999, 20, 1108.

13. Scheerder, J.; Fochi, M.; Engbersen, J.F.J.; Reinhoudt, D.N. J. Org. Chem. 1994, $59,7815$. 
14. Scheerder, J.; Engbersen, J.F.J.; Casnati, A.; Ungaro, R.; Reinhoudt, D.N. J. Org. Chem. 1995, 60, 6448.

15. Georgiev, E.M.; Wolf, N.; Roundhill, D.M. Polyhedron 1997, 16, 1581.

16. Beer, P.D.; Drew, M.G.B.; Gradwell, K. J. Chem. Soc. Perkin Trans. 2 2000, 511.

17. Wróblewski, W.; Brzózka, Z.; Rudkevich, D.M.; Reinhoudt, D.N. Sensors \& Actuators B 1996, 37, 151.

18. Rudkevich, D.M.; Verboom, W.; Reinhoudt, D.N. Tetrahedron Lett. 1994, 35, 7131.

19. Rudkevich, D.M.; Verboom, W.; Reinhoudt, D.N. J. Org. Chem. 1994, 59, 3683.

20. Malinowska, E.; Niedziolka, J.; Meyerhoff, M.E. Anal. Chim. Acta 2001, 432, 67.

21. Malinowska, E.; Gorski, L.; Meyerhoff, M.E. Anal. Chim. Acta 2002, 468, 133.

22. Maeda, H.; Osuka, A.; Furuta, H. J. Incl. Phenom. 2004, 49, 33.

23. Savage, P.B. ; Holmgren, S.K. ; Gellman, S.H. J. Am. Chem. Soc. 1994, 116, 4069.

24. Casabo, J.; Eschriche, L.; Perez-Jimenez, C.; Errachid, A. Anal. Chim. Acta 1996, $320,63$.

25. Pomecko, R.; Asfari, Z.; Hubscher-Bruder, V.; Arnaud-Neu, F.; Vicens, J.; Bochenska, M. XXVIIIth International Symposium on Macrocylic Chemistry, Gdansk University of Technology, Gdansk, Poland, 13-18 July 2003.

26. Hamdi, A.; Nam, K.C.; Ryu, B.J.; Kim, J.S.; Vicens, J. Tetrahedron Lett. 2004, 45, 4689.

27. Gampp, H.; Maeder, M.; Meyer, C.J.; Zuberbühler, A.D. Talanta 1986, 33, 943.

28. Bochenska, M.; Zielinska, A.; Pomecko, R.; Hubscher-Bruder, V.; Arnaud-Neu, F. J. Incl. Phenom. 2005, 52, 129. 
29. Umezawa, Y.; Buhlmann, P.; Umezawa, K.; Tohda, K.; Amemiya, S. Pure Appl. Chem. 2000, 72, 1851, see also Umezawa, Y.; Buhlmann, P.; Umezawa, K.; Hamada, N.; Aoki, H. Pure Appl. Chem. 2002, 74, 923.

30. Moyer, B.A.; Bonnesen, P.V. in Supramolecular Chemistry of Anions, Bianchi, A., Bowman-James, K., Garcia-Espana, E., Eds.; John Wiley-VCH: New York, 1997; ch. 1, p. 1.

31. Schaller, U.; Bakker, E.; Spichiger, U.E.; Pretsch, E. Anal. Chem., 1994, 66, 391.

32. Bakker, E.; Malinowska, E.; Schiller, R.D.; Meyerhoff, M.E. Talanta 1994, 41, 881.

33. Amemiya, S.; Buhlmann, P.; Pretsch, E.; Rusterholz, B.; Umezawa, Y. Anal. Chem. 2000, 72, 1618.

34. Egorov, V.V.; Rakhmanko, E.M.; Okaev, E.; Nazarov, V.; Pomelyenok, E.; Pavlova, T. Electroanalysis 2004, 16, 1459.

35. Lizondo-Sabater, J.; Segui, M-J.; Martinez-Manez, R. Sens. Actu. B, 2004, 101, 20

36. Segui, M-J.; Sancenon, F.; Martinez-Manez, R. Analyst, 2002, 127, 387

URL: http:/mc.manuscriptcentral.com/tandf/gsch Email: suprachem@mail.cm.utexas.edu 
Figure Captions

Figure 1. Changes in ${ }^{1} \mathrm{H}$ NMR spectra of 2 in presence of $\mathrm{ClO}_{4}{ }^{-}$anion .

Figure 2. Potentiometric responses of electrode with ligand 2 to anions in $\mathrm{MES} / \mathrm{NaOH}$ buffer $(\mathrm{pH}=5.5)$ and ionic strength adjusted with $10 \mathrm{mM} \mathrm{NaCl}$ solution.

URL: http:/mc.manuscriptcentral.com/tandf/gsch Email: suprachem@mail.cm.utexas.edu 
Table 1 Most important changes $\Delta(\delta)$ in the proton ${ }^{\mathrm{a}}$ chemical shifts $(\delta)[\mathrm{ppm}]$ experienced by 2 in presence of $\mathrm{I}^{-}, \mathrm{SCN}^{-}$and $\mathrm{ClO}_{4}{ }^{-}$anions in $\mathrm{CDCl}_{3}$

\begin{tabular}{cccccc}
\hline & $\mathrm{c}$ & $\mathrm{e}$ & $\mathrm{f}$ & $\mathrm{g}$ & $\mathrm{j}$ \\
\hline$\delta(\mathbf{2})$ & 6.63 & 2.91 & 4.23 & 3.87 & 3.94 \\
$\delta(\mathbf{2}+\mathrm{NaI})$ & 6.93 & 3.35 & 4.42 & 4.40 & 4.00 \\
$\Delta(\delta)$ & 0.30 & 0.44 & 0.19 & 0.53 & -0.06 \\
$\delta(\mathbf{2}+\mathrm{NaSCN})$ & 6.95 & 3.33 & 4.39 & 4.27 & 3.76 \\
$\Delta(\delta)$ & 0.32 & 0.42 & 0.16 & 0.40 & -0.18 \\
$\delta\left(\mathbf{2}+\mathrm{NaClO}_{4}\right)$ & 6.95 & 3.35 & 4.40 & 4.27 & 3.47 \\
$\Delta(\delta)$ & 0.32 & 0.44 & 0.17 & 0.40 & -0.47
\end{tabular}

${ }^{a}$ for the attribution of the protons see Fig. 1.

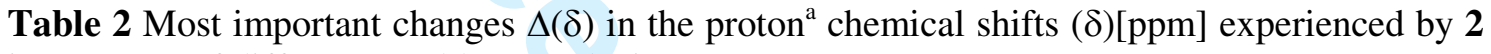
in presence of different perchlorate salts in $\mathrm{CD}_{3} \mathrm{CN}$.

\begin{tabular}{cccccc}
\hline & $\mathrm{c}$ & $\mathrm{e}$ & $\mathrm{f}$ & $\mathrm{g}$ & $\mathrm{j}$ \\
\hline$\delta(\mathbf{2})$ & 6.87 & 2.93 & 4.15 & 3.74 & 3.81 \\
$\delta\left(\mathbf{2}+\mathrm{LiClO}_{4}\right)$ & 7.19 & 3.28 & 4.21 & 4.36 & 3.29 \\
$\Delta(\delta)$ & 0.32 & 0.35 & 0.06 & 0.62 & -0.52 \\
$\delta\left(\mathbf{2}+\mathrm{NaClO}_{4}\right)$ & 7.22 & 3.33 & 4.21 & 4.09 & 3.28 \\
$\Delta(\delta)$ & 0.35 & 0.40 & 0.06 & 0.35 & -0.53 \\
$\delta\left(\mathbf{2}+\mathrm{CsClO}_{4}\right)$ & 6.86 & 2.92 & 4.14 & 3.75 & 3.75 \\
$\Delta(\delta)$ & -0.01 & -0.01 & -0.01 & 0.01 & -0.06 \\
$\delta\left(\mathbf{2}+\mathrm{NEt}_{4} \mathrm{ClO}_{4}\right)$ & 6.93 & 3.00 & 4.22 & 3.83 & 3.57 \\
$\Delta(\delta)$ & 0.06 & 0.07 & 0.07 & 0.09 & -0.24 \\
$\delta(\mathbf{2 a})$ & 6.80 & 2.87 & 4.09 & 3.77 & 3.06 \\
$\delta\left(\mathbf{2 a}+\mathrm{NaClO}_{4}\right)$ & 7.19 & 3.31 & 4.19 & 4.06 & 3.27 \\
$\Delta(\delta)$ & 0.39 & 0.44 & 0.10 & 0.29 & 0.21 \\
\hline
\end{tabular}

${ }^{a}$ for the attribution of the protons see Fig. 1. 
Table 3 Characteristics of the electrode potentiometric response towards chosen primary anions in the presence of $10 \mathrm{mM} \mathrm{NaCl}$. Electrodes with PVC/o-NPOE (1/2) membrane containing 2\% wt. of 2 or 4.

\begin{tabular}{|c|c|c|c|}
\hline $\begin{array}{l}\text { Ligand, } \\
\text { Inner and conditioning electrolyte }\end{array}$ & $\begin{array}{c}\text { Primary } \\
\text { anion }\end{array}$ & $\begin{array}{c}\mathrm{DL}^{\mathrm{a}} \\
(\log a)\end{array}$ & $\begin{array}{l}\text { Slope } \\
(\mathrm{mV})\end{array}$ \\
\hline (2), $\mathrm{MES} / \mathrm{NaOH} / 10^{-2} \mathrm{M} \mathrm{NaCl}(\mathrm{pH}=5.5)$ & $\mathrm{ClO}_{4}^{-}$ & -7.0 & -58 \\
\hline (2), Water solution & $\mathrm{ClO}_{4}^{-}$ & -5.5 & -55 \\
\hline (2), $\mathrm{MES} / \mathrm{NaOH} / 10^{-2} \mathrm{M} \mathrm{NaCl}(\mathrm{pH}=5.5)$ & $\mathrm{SCN}^{-}$ & -6.0 & -55 \\
\hline (2), $\mathrm{MES} / \mathrm{NaOH} / 10^{-2} \mathrm{M} \mathrm{NaCl}(\mathrm{pH}=5.5)$ & $\mathrm{I}^{-}$ & -6.0 & -52 \\
\hline (2), $\mathrm{MES} / \mathrm{NaOH} / 10^{-2} \mathrm{M} \mathrm{NaCl}(\mathrm{pH}=5.5)$ & $\mathrm{NO}_{3}^{-}$ & -5.0 & -51 \\
\hline (2), $\mathrm{MES} / \mathrm{NaOH} / 10^{-2} \mathrm{M} \mathrm{NaCl}(\mathrm{pH}=5.5)$ & $\mathrm{Br}^{-}$ & -4.0 & -44 \\
\hline (2), $\mathrm{MES} / \mathrm{NaOH} / 10^{-2} \mathrm{M} \mathrm{NaCl}(\mathrm{pH}=5.5)$ & $\mathrm{Cr}_{2} \mathrm{O}_{7}^{2-}$ & -5.5 & -47 \\
\hline (4), $\mathrm{MES} / \mathrm{NaOH} / 10^{-2} \mathrm{M} \mathrm{NaCl}(\mathrm{pH}=5.5)$ & $\mathrm{ClO}_{4}^{-}$ & -6.0 & -49 \\
\hline
\end{tabular}

${ }^{a}$ DL: detection limit.

Table 4 Selectivity coefficients, $\log K_{I, J}^{p o t}$ of electrodes containing ligand $\mathbf{2}$ or $\mathbf{4}$, determined in buffered $(\mathrm{pH}=5.5)$ and unbuffered $(\mathrm{pH}=6.5$ or 6.0$)$ sodium salts solutions by FIM or SSM.

\begin{tabular}{ccccccccc}
$\begin{array}{c}\text { Ligand/M } \\
\text { ethod }\end{array}$ & $\mathrm{pH}$ & $\mathrm{ClO}_{4}^{-}$ & $\mathrm{SCN}^{-}$ & $\mathrm{I}^{-}$ & $\mathrm{NO}_{3}^{-}$ & $\mathrm{Br}^{-}$ & $\mathrm{Cl}^{-}$ & $\mathrm{Cr}_{2} \mathrm{O}_{7}^{2-}$ \\
\hline $\mathbf{2} / \mathrm{FIM}$ & 5.5 & 0 & -1.2 & -1.8 & -2.6 & -3.0 & $<-4.0$ & - \\
$\mathbf{2} / \mathrm{SSM}$ & 5.5 & 0 & -1.3 & -2.0 & -2.9 & -4.0 & $<-4.0$ & -1.9 \\
$\mathbf{2} / \mathrm{SSM}$ & 6.5 & 0 & -1.4 & -1.9 & -3.1 & -3.5 & $<-4.0$ & -1.8 \\
$\mathbf{2} / \mathrm{FIM}$ & 6.0 & 0 & -1.7 & -2.3 & -2.4 & -3.0 & -4.1 & - \\
$\mathbf{4} / \mathrm{SSM}$ & 5.5 & 0 & -1.1 & -1.6 & -2.5 & -3.5 & $<-4.0$ & -1.9 \\
\hline
\end{tabular}

URL: http:/mc.manuscriptcentral.com/tandf/gsch Email: suprachem@mail.cm.utexas.edu 
Table 5. Comparison of potentiometric properties of electrodes based on different perchlorate selective compounds.

\begin{tabular}{|c|c|c|c|c|c|}
\hline & 2 & TDMACl $^{\mathrm{a}}$ & PS2M $^{b}$ & cyclam $^{\mathrm{c}}$ & {$[\mathrm{Cu}(\text { cyclam })]^{2+, d}$} \\
\hline $\begin{array}{c}\mathrm{S}[\mathrm{mV}] \\
\mathrm{DL}\left[\mathrm{mol} / \mathrm{dm}^{3}\right]\end{array}$ & $\begin{array}{l}58.0 \\
10^{-7} \\
\end{array}$ & - & $\begin{array}{c}-56.0 \\
8 \times 10^{-7} \\
\end{array}$ & $\begin{array}{c}-52.5 \\
4.2 \times 10^{-6} \\
\end{array}$ & $\begin{array}{c}66.0 \\
1.8 \times 10^{-5} \\
\end{array}$ \\
\hline $\mathrm{X}^{-}$ & \multicolumn{5}{|c|}{$\log \mathrm{K}^{\mathrm{pot}} \mathrm{ClO}_{4}^{-,} \mathrm{X}$} \\
\hline $\mathrm{ClO}_{4}^{-}$ & 0 & 0 & 0 & 0 & 0 \\
\hline $\mathrm{SCN}^{-}$ & -1.3 & -1.2 & -1.0 & - & -1.3 \\
\hline $\mathrm{I}^{-}$ & -2.0 & -1.6 & -1.8 & - & -1.5 \\
\hline $\mathrm{NO}_{3}^{-}$ & -2.9 & -3.0 & -2.6 & -2.6 & -2.2 \\
\hline $\mathrm{Br}^{-}$ & -4.0 & -3.8 & -4.1 & -3.1 & -2.2 \\
\hline $\mathrm{Cl}^{-}$ & $<-4.0$ & -5.0 & -5.0 & -3.2 & -2.1 \\
\hline $\mathrm{HCO}_{3}^{-}$ & - & -6.4 & -4.0 & -2.4 & -2.2 \\
\hline $\mathrm{HPO}_{4}{ }^{2-}$ & - & - & -5.2 & -3.8 & -2.8 \\
\hline $\mathrm{SO}_{4}{ }^{2-}$ & - & -7.7 & -5.0 & -4.4 & - \\
\hline
\end{tabular}

a) tridodecyl-methyl ammonium chloride 7-phenyl-7-phospha-3,11-dithiabicyclo[11,4,0]heptadeca-13(1),14,16-triene (PS2M); from ref.24 1,4,8,11-tetra(n-octyl)-1,4,8,11-tetraazacyclotetradecane (cyclam); from ref.35 from ref.36 
Scheme 1
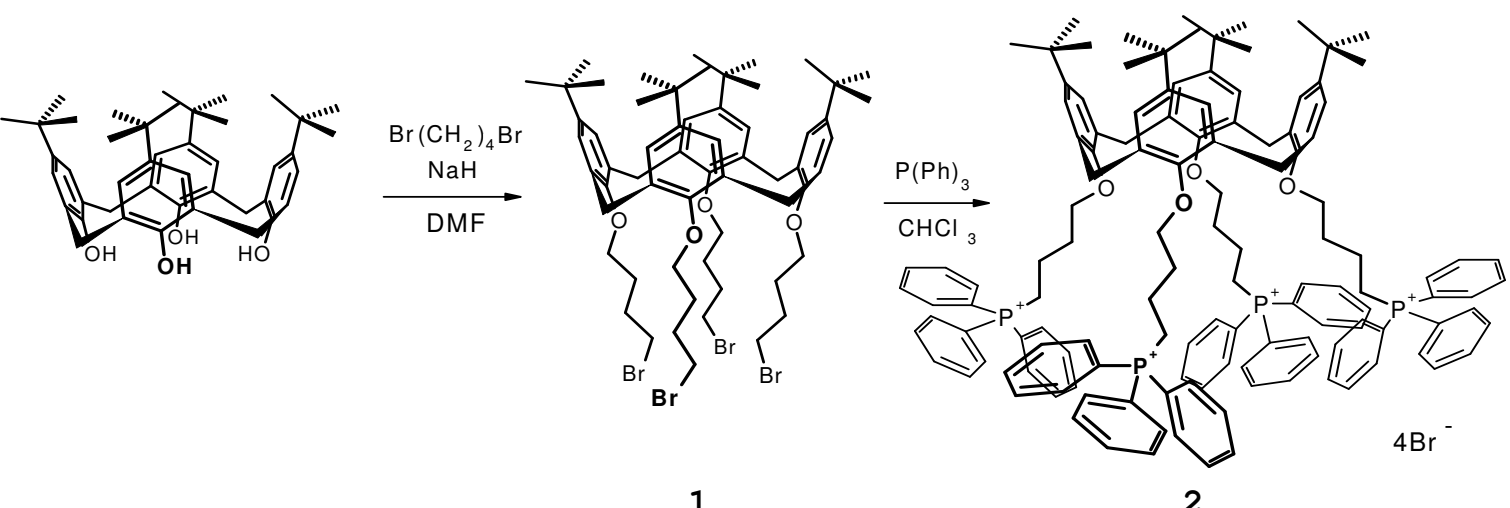

1

Scheme 1 
Scheme 2

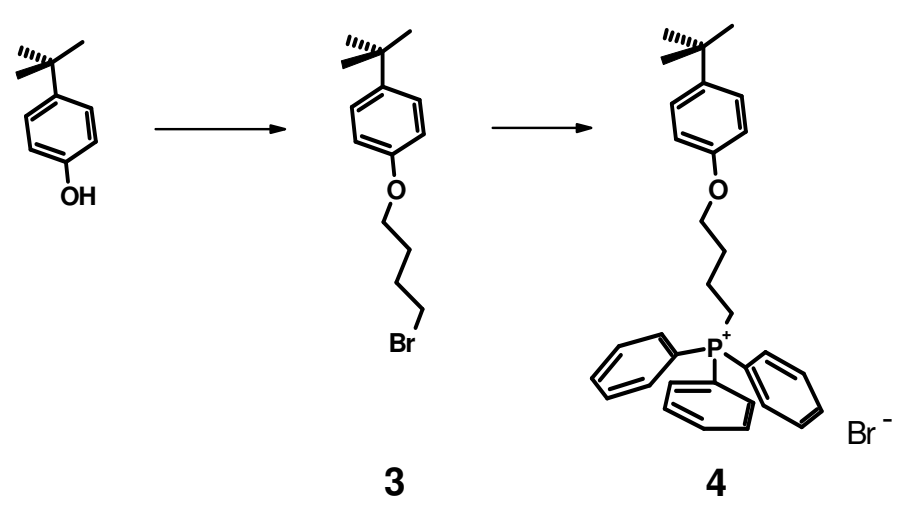

Scheme 2 
Fig.1

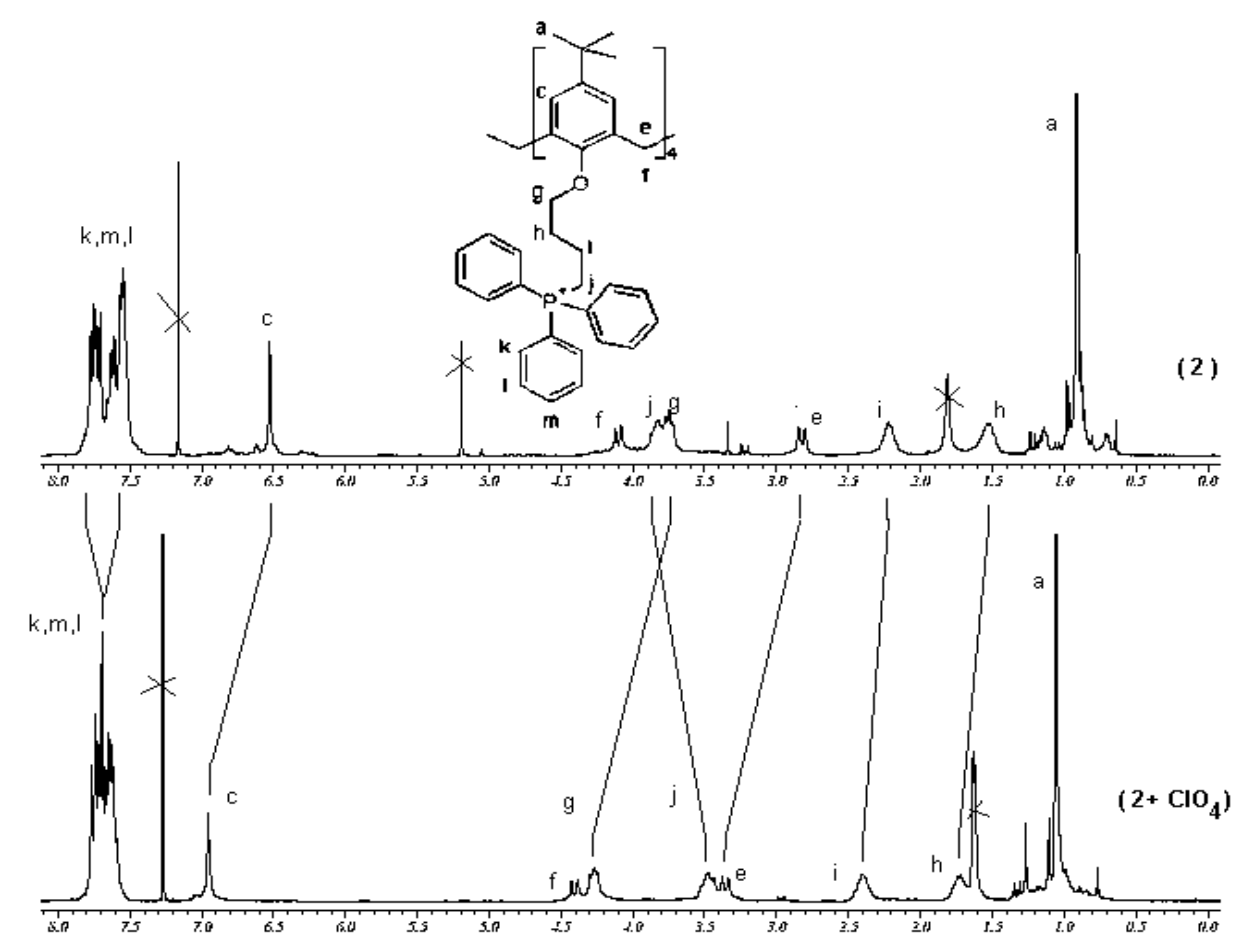

Fig. 1 Changes in ${ }^{1} \mathrm{H}$ NMR spectra of 2 in presence of $\mathrm{NaClO}_{4}$.

URL: http:/mc.manuscriptcentral.com/tandf/gsch Email: suprachem@mail.cm.utexas.edu 
Fig. 2

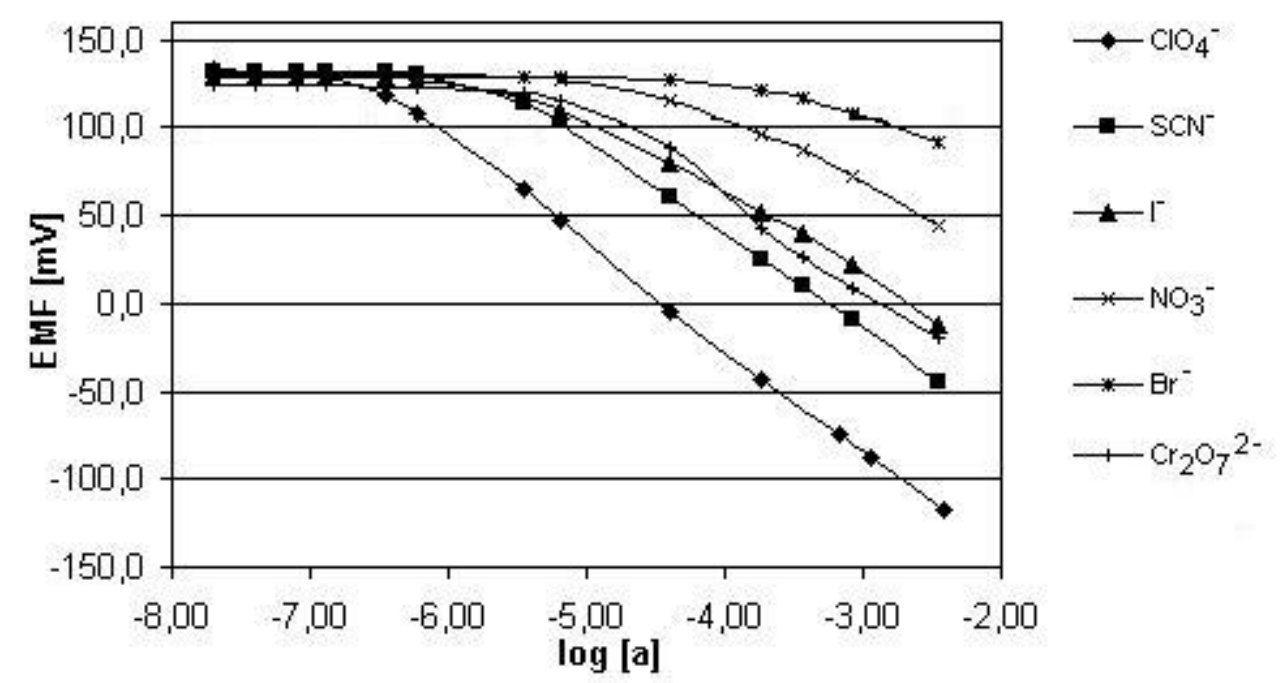

Fig.2 Potentiometric responses of electrode with ligand 2 to anions in MES/NaOH buffer $(\mathrm{pH}=5.5)$ and ionic strength adjusted with $10 \mathrm{mM} \mathrm{NaCl}$ solution. 


1
2
3
4
5
6
7
8
9
10
11
12
13
14
15
16
17
18
19
20
21
22
23
24
25
26
27
28
29
30
31
32
33
34
35
36
37
38
39
40
41
42
43
44
45
46
47
48
49
50
51
52
53
54
55
56
57
59
60

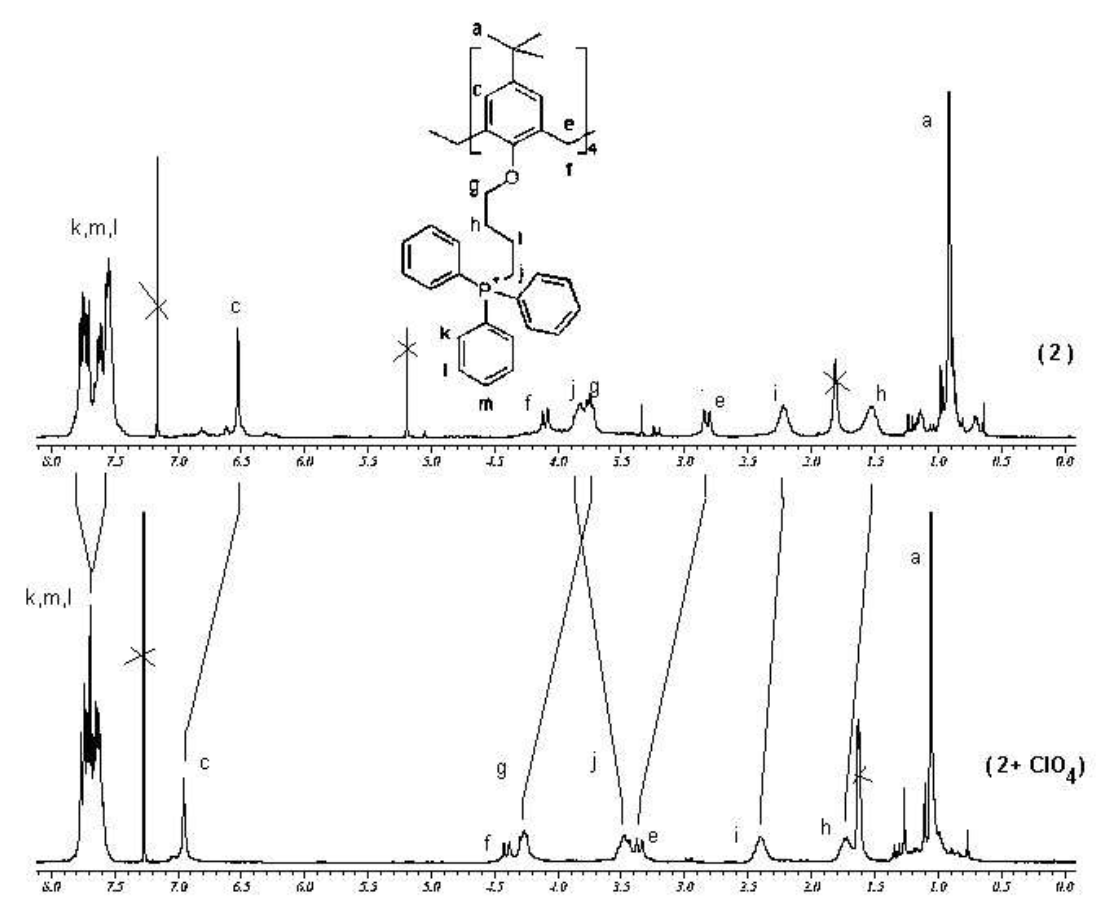

$282 \times 211 \mathrm{~mm}(72 \times 72$ DPI $)$

URL: http:/mc.manuscriptcentral.com/tandf/gsch Email: suprachem@mail.cm.utexas.edu 


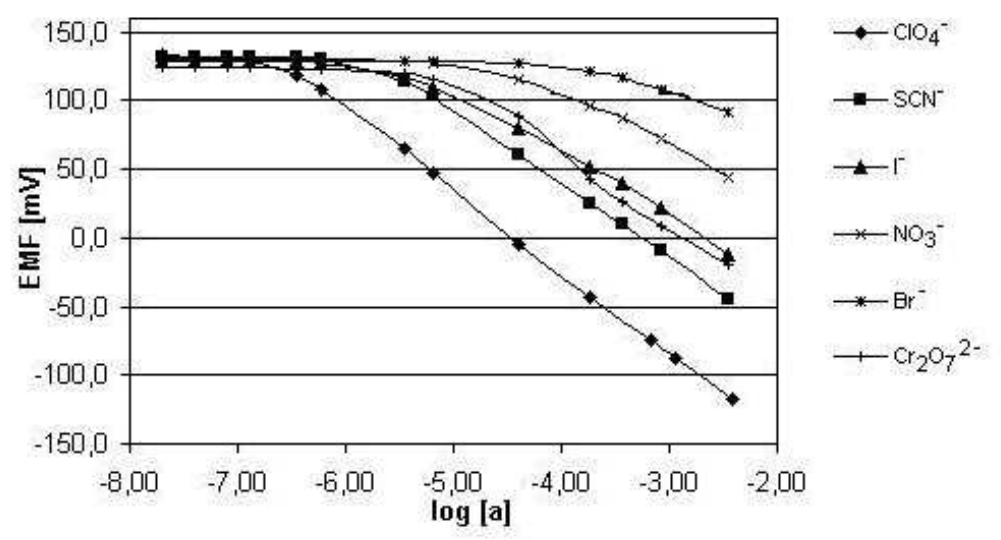

$225 \times 169 \mathrm{~mm}(72 \times 72$ DPI $)$ 
Table 1 Most important changes $\Delta(\delta)$ in the proton ${ }^{\mathrm{a}}$ chemical shifts $(\delta)[\mathrm{ppm}]$ experienced by $\mathbf{2}$ in presence of $\mathrm{I}^{-}, \mathrm{SCN}^{-}$and $\mathrm{ClO}_{4}^{-}$anions in $\mathrm{CDCl}_{3}$

\begin{tabular}{cccccc} 
& $\mathrm{c}$ & $\mathrm{e}$ & $\mathrm{f}$ & $\mathrm{g}$ & $\mathrm{j}$ \\
\hline$\delta(\mathbf{2})$ & 6.63 & 2.91 & 4.23 & 3.87 & 3.94 \\
$\delta(\mathbf{2}+\mathrm{NaI})$ & 6.93 & 3.35 & 4.42 & 4.40 & 4.00 \\
$\Delta(\delta)$ & 0.30 & 0.44 & 0.19 & 0.53 & -0.06 \\
$\delta(\mathbf{2}+\mathrm{NaSCN})$ & 6.95 & 3.33 & 4.39 & 4.27 & 3.76 \\
$\Delta(\delta)$ & 0.32 & 0.42 & 0.16 & 0.40 & -0.18 \\
$\delta\left(\mathbf{2}+\mathrm{NaClO}_{4}\right)$ & 6.95 & 3.35 & 4.40 & 4.27 & 3.47 \\
$\Delta(\delta)$ & 0.32 & 0.44 & 0.17 & 0.40 & -0.47 \\
\hline
\end{tabular}

${ }^{a}$ for the attribution of the protons see Fig. 1.

Table 2 Most important changes $\Delta(\delta)$ in the proton ${ }^{\mathrm{a}}$ chemical shifts $(\delta)[\mathrm{ppm}]$ experienced by $\mathbf{2}$ and $\mathbf{2 a}$ in presence of different perchlorate salts in $\mathrm{CD}_{3} \mathrm{CN}$.

\begin{tabular}{cccccc}
\hline & $\mathrm{c}$ & $\mathrm{e}$ & $\mathrm{f}$ & $\mathrm{g}$ & $\mathrm{j}$ \\
\hline$\delta(\mathbf{2})$ & 6.87 & 2.93 & 4.15 & 3.74 & 3.81 \\
$\delta\left(\mathbf{2}+\mathrm{LiClO}_{4}\right)$ & 7.19 & 3.28 & 4.21 & 4.36 & 3.29 \\
$\Delta(\delta)$ & 0.32 & 0.35 & 0.06 & 0.62 & -0.52 \\
$\delta\left(\mathbf{2}+\mathrm{NaClO}_{4}\right)$ & 7.22 & 3.33 & 4.21 & 4.09 & 3.28 \\
$\Delta(\delta)$ & 0.35 & 0.40 & 0.06 & 0.35 & -0.53 \\
$\delta\left(\mathbf{2}+\mathrm{CsClO}_{4}\right)$ & 6.86 & 2.92 & 4.14 & 3.75 & 3.75 \\
$\Delta(\delta)$ & -0.01 & -0.01 & -0.01 & 0.01 & -0.06 \\
$\delta\left(\mathbf{2}+\mathrm{NEt}_{4} \mathrm{ClO}_{4}\right)$ & 6.93 & 3.00 & 4.22 & 3.83 & 3.57 \\
$\Delta(\delta)$ & 0.06 & 0.07 & 0.07 & 0.09 & -0.24 \\
$\delta(\mathbf{2 a})$ & 6.80 & 2.87 & 4.09 & 3.77 & 3.06 \\
$\delta\left(\mathbf{2} \mathbf{a}+\mathrm{NaClO}_{4}\right)$ & 7.19 & 3.31 & 4.19 & 4.06 & 3.27 \\
$\Delta(\delta)$ & 0.39 & 0.44 & 0.10 & 0.29 & 0.21 \\
\hline
\end{tabular}

${ }^{a}$ for the attribution of the protons see Fig. 1. 
1

Table 3 Characteristics of the electrode potentiometric response towards chosen primary anions in the presence of $10 \mathrm{mM} \mathrm{NaCl}$. Electrodes with PVC/o-NPOE (1/2) membrane containing 2\% wt. of 2 or 4.

\begin{tabular}{|c|c|c|c|}
\hline $\begin{array}{l}\text { Ligand, } \\
\text { Inner and conditioning electrolyte }\end{array}$ & $\begin{array}{l}\text { Primary } \\
\text { anion }\end{array}$ & $\begin{array}{c}\mathrm{DL}^{\mathrm{a}} \\
(\log a)\end{array}$ & $\begin{array}{l}\text { Slope } \\
(\mathrm{mV})\end{array}$ \\
\hline (2), $\mathrm{MES} / \mathrm{NaOH} / 10^{-2} \mathrm{M} \mathrm{NaCl}(\mathrm{pH}=5.5)$ & $\mathrm{ClO}_{4}^{-}$ & -7.0 & -58 \\
\hline (2), Water solution & $\mathrm{ClO}_{4}^{-}$ & -5.5 & -55 \\
\hline (2), $\mathrm{MES} / \mathrm{NaOH} / 10^{-2} \mathrm{M} \mathrm{NaCl}(\mathrm{pH}=5.5)$ & $\mathrm{SCN}^{-}$ & -6.0 & -55 \\
\hline (2), $\mathrm{MES} / \mathrm{NaOH} / 10^{-2} \mathrm{M} \mathrm{NaCl}(\mathrm{pH}=5.5)$ & $\mathrm{I}^{-}$ & -6.0 & -52 \\
\hline (2), $\mathrm{MES} / \mathrm{NaOH} / 10^{-2} \mathrm{M} \mathrm{NaCl}(\mathrm{pH}=5.5)$ & $\mathrm{NO}_{3}^{-}$ & -5.0 & -51 \\
\hline (2), $\mathrm{MES} / \mathrm{NaOH} / 10^{-2} \mathrm{M} \mathrm{NaCl}(\mathrm{pH}=5.5)$ & $\mathrm{Br}^{-}$ & -4.0 & -44 \\
\hline (2), $\mathrm{MES} / \mathrm{NaOH} / 10^{-2} \mathrm{M} \mathrm{NaCl}(\mathrm{pH}=5.5)$ & $\mathrm{Cr}_{2} \mathrm{O}_{7}^{2-}$ & -5.5 & -47 \\
\hline (4), $\mathrm{MES} / \mathrm{NaOH} / 10^{-2} \mathrm{M} \mathrm{NaCl}(\mathrm{pH}=5.5)$ & $\mathrm{ClO}_{4}^{-}$ & -6.0 & -49 \\
\hline
\end{tabular}

${ }^{a}$ DL: detection limit.

Table 4 Selectivity coefficients, $\log K_{I, J}^{\text {pot }}$ of electrodes containing ligand $\mathbf{2}$ or $\mathbf{4}$, determined in buffered $(\mathrm{pH}=5.5)$ and unbuffered $(\mathrm{pH}=6.5$ or 6.0$)$ sodium salts solutions by FIM or SSM.

\begin{tabular}{ccccccccc}
$\begin{array}{c}\text { Ligand } \\
\text { /Method }\end{array}$ & $\mathrm{pH}$ & $\mathrm{ClO}_{4}^{-}$ & $\mathrm{SCN}^{-}$ & $\mathrm{I}^{-}$ & $\mathrm{NO}_{3}^{-}$ & $\mathrm{Br}^{-}$ & $\mathrm{Cl}^{-}$ & $\mathrm{Cr}_{2} \mathrm{O}_{7}^{2-}$ \\
\hline $\mathbf{2} / \mathrm{FIM}$ & 5.5 & 0 & -1.2 & -1.8 & -2.6 & -3.0 & $<-4.0$ & - \\
$\mathbf{2} / \mathrm{SSM}$ & 5.5 & 0 & -1.3 & -2.0 & -2.9 & -4.0 & $<-4.0$ & -1.9 \\
$\mathbf{2} / \mathrm{SSM}$ & 6.5 & 0 & -1.4 & -1.9 & -3.1 & -3.5 & $<-4.0$ & -1.8 \\
$\mathbf{2} / \mathrm{FIM}$ & 6.0 & 0 & -1.7 & -2.3 & -2.4 & -3.0 & -4.1 & - \\
$\mathbf{4} / \mathrm{SSM}$ & 5.5 & 0 & -1.1 & -1.6 & -2.5 & -3.5 & $<-4.0$ & -1.9 \\
\hline
\end{tabular}


Table 5 Comparison of potentiometric properties of electrodes based on different perchlorate selective compounds.

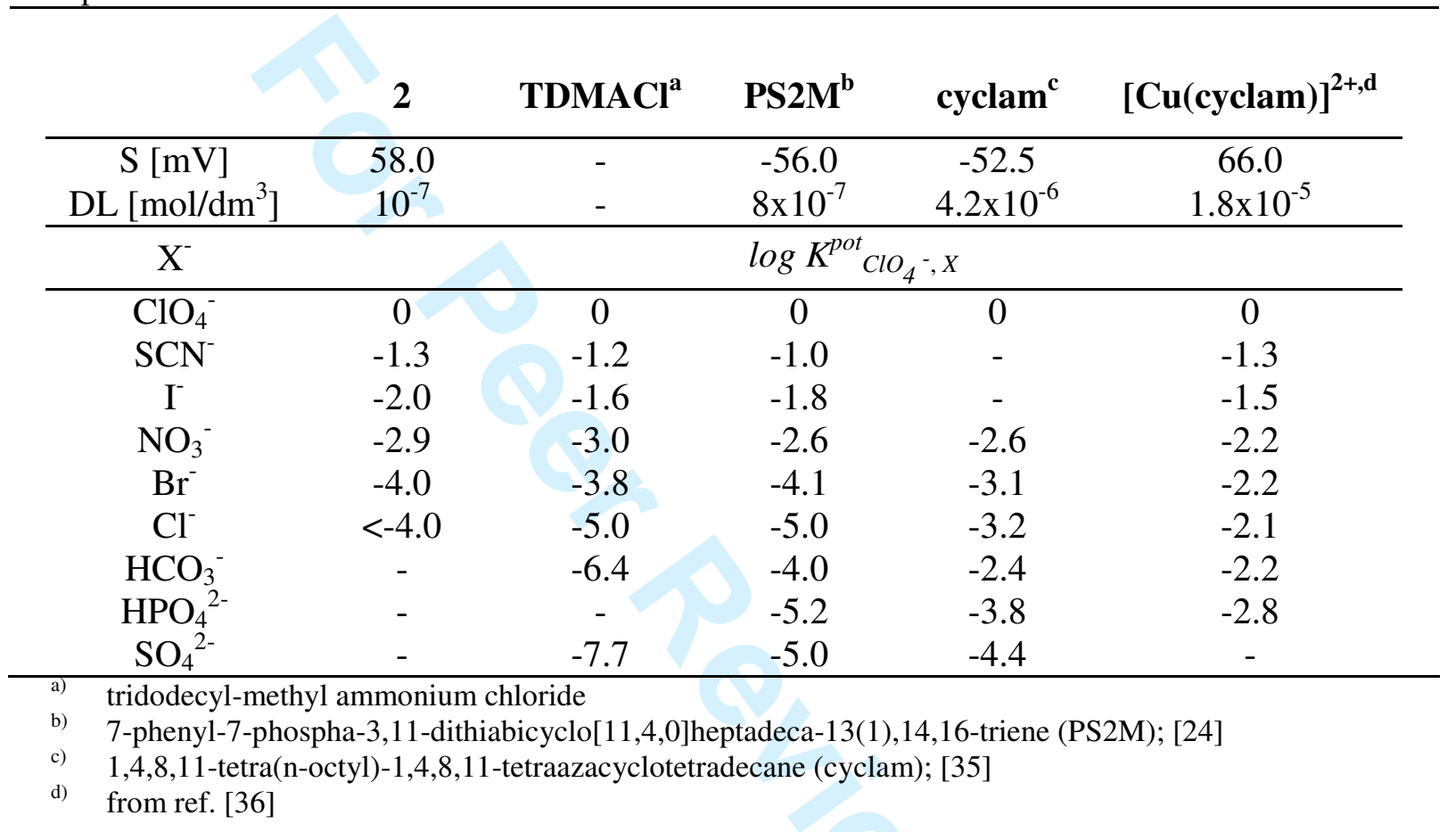


1

2

3

4

5

6

7

8

9

10

11

12

13

14

15

16

17

18

19

20

21

22

23

24

25

26

27

28

29

30

31

32

33

34

35

36

37

38

39

40

41

42

43

44

45

46

47

48

49

50

51

52

53

54

55

56

57

58

59

60

Attached Files (8 files):

RP Main Publication - Word 2003 .doc document

RP Tables - Word 2003 .doc document

RP scheme 1, RP scheme 2 - ChemDraw 10 drawing .cdx

RP figure 1, RP figure 2 - graphics in tiff format

RP Gabstract.doc - graphical abstract word .doc document

RP Gabstract.pdf - graphical abstract .pdf document

The documents were edited using Office 2003, ChemDraw 10, Gimp 2.2 on Windows XP platform 